Forthcoming in Quarterly

Journal of Economics

\title{
RELATIONAL CONTRACTS AND THE THEORY OF THE FIRM*
}

\author{
George Baker \\ Robert Gibbons \\ Kevin J. Murphy
}

June 2, 2001

\begin{abstract}
Relational contracts-informal agreements sustained by the value of future relationships-are prevalent within and between firms. We develop repeated-game models showing why and how relational contracts within firms (vertical integration) differ from those between (non-integration). We show that integration affects the parties' temptations to renege on a given relational contract, and hence affects the best relational contract the parties can sustain. In this sense, the integration decision can be an instrument in the service of the parties' relationship. Our approach also has implications for joint ventures, alliances, and networks, and for the role of management within and between firms.
\end{abstract}

\footnotetext{
*We are grateful for research support from: the Division of Research at Harvard Business School (Baker); MIT's Sloan School, MIT's Center for Innovation in Product Development, and the NSF (through grant SBR9809107) (Gibbons); and USC's Marshall School (Murphy). We thank Alexander Dyck, Oliver Hart, Rebecca Henderson, Bengt Holmstrom, Edward Lazear, Patrick Legros, Jonathan Levin, Bentley MacLeod, John Matsusaka, Kevin Murdoch, Canice Prendergast, Julio Rotemberg, Steven Tadelis, Mike Waldman, Mike Whinston, the referees, and especially Benjamin Klein for helpful comments.
} 


\section{RELATIONAL CONTRACTS AND THE THEORY OF THE FIRM}

\section{INTRODUCTION}

Firms are riddled with relational contracts: informal agreements and unwritten codes of conduct that powerfully affect the behaviors of individuals within firms. There are often informal quid pro quos between co-workers, as well as unwritten understandings between bosses and subordinates about task-assignment, promotion, and termination decisions. ${ }^{1}$ Even ostensibly formal processes such as compensation, transfer pricing, internal auditing, and capital budgeting often cannot be understood without consideration of their associated informal agreements. $^{2}$

Business dealings are also riddled with relational contracts. Supply chains often involve long-run, hand-in-glove supplier relationships through which the parties reach accommodations when unforeseen or uncontracted-for events occur. ${ }^{3}$ Similar relationships also exist horizontally, as in the networks of firms in the fashion industry or the diamond trade, and in strategic alliances, joint ventures, and business groups. ${ }^{4}$ Whether vertical or horizontal, these relational contracts influence the behaviors of firms in their dealings with other firms.

Relational contracts within and between firms help circumvent difficulties in formal contracting (i.e., contracting enforced by a third party, such as a court). For example, a formal contract must be specified ex ante in terms that can be verified ex post by the third party, whereas a relational contract can be based on outcomes that are observed by only the contracting parties ex post, and also on outcomes that are prohibitively costly to specify ex ante.

1. Many observers have emphasized the importance of informal agreements in organizations, including Barnard [1938], Simon [1947], Selznick [1949], Gouldner [1954], and Blau [1955].

2. See Lawler [1971] on compensation, Eccles [1985] on transfer pricing, Dalton [1959] on internal auditing, and Bower [1970] on capital budgeting.

3. Macaulay [1963] emphasized the importance of such "non-contractual relations" between various businesses. Dore [1983] was the first of many to describe Japanese supply relationships in these terms; see Cusumano and Takeishi [1991], Nishiguchi [1994], and Sako and Helper [1998] for recent contributions.

4. In "Neither Market Nor Hierarchy: Network Forms of Organization," Powell [1990] describes a variety of networks and emphasizes their differences from markets and firms; see Podolny and Page [1998] for a summary and critique of subsequent work. On alliances, see Gerlach [1991] and Gulati and Singh [1998]; on joint ventures, Kogut [1989] and Pisano [1989]; on business groups, Granovetter [1995] and Dyer [1996]; and on "virtual" firms, Chesbrough and Teece [1996]. 
A relational contract thus allows the parties to utilize their detailed knowledge of their specific situation and to adapt to new information as it becomes available. For the same reasons, however, relational contracts cannot be enforced by a third party and so must be self-enforcing: the value of the future relationship must be sufficiently large that neither party wishes to renege. 5

In this paper we develop repeated-game models of relational contracts both within and between firms. We show why and how relational contracts within firms differ from those between. In particular, we find that integration affects the parties' temptations to renege on a given relational contract. Thus, in a given environment, a desirable relational contract might be feasible under integration but not under non-integration (or the reverse). This result motivates a new perspective on vertical integration: a major factor in the vertical-integration decision is whether integration or non-integration facilitates the superior relational contract. In short, integration can be an instrument in the service of the parties' relationship.

Section II develops a model in which an upstream party uses an asset to produce a good that can be used in a downstream party's production process. We follow Grossman and Hart's [1986] terminology: when the upstream party owns the asset we call the transaction nonintegrated - the upstream party is an independent contractor, working with an asset she owns; when the downstream party owns the asset we call the transaction integrated-the upstream party is an employee, working with an asset owned by the firm. We assume that ownership of the asset conveys ownership of the good. (In fact, the asset could simply be the legal title to the good.) Thus, if the upstream party owns the asset then the downstream party cannot use the good without buying it from the upstream party, whereas if the downstream party owns the asset then he already owns the good. In addition, we assume that the good produced by the upstream party can be used either in the downstream party's production process or in an alternative use, and that the upstream party's actions affect the good's value in both these uses.

Under either ownership structure, the downstream party would like the upstream party to take actions that improve the value of the good in the downstream production process. We focus on actions that are unobservable (moral hazard) and outcomes that are observable but not verifiable (non-contractibility). In such a setting, relational contracts can encourage useful actions: the downstream party can promise to pay the upstream party a bonus if she produces a

5. Accordingly, contracts we call "relational" are sometimes called "self-enforcing" [Telser, 1981; Klein, 1996], "implicit" [MacLeod and Malcomson, 1989], or both [Bull, 1987]. Our use of "relational" follows the legal literature, particularly Macneil [1978]. Those who call relational contracts "implicit" naturally call formal contracts "explicit," but this usage risks connoting that implicit contracts are vague, when in practice it is often important that relational contracts be clearly understood. 
good of high value. Because this promise is based on non-contractible outcomes, it provides incentives to the upstream party only if it is self-enforcing (i.e., the short-run value of reneging must be less than the long-run value of the relationship).

The key question in our analysis is whether choosing appropriate asset ownership (integration or non-integration) can make a given promise self-enforcing. Under integration, if the downstream party reneges on the bonus, he still owns the good. But under non-integration, if the downstream party reneges on the bonus, he cannot use the good without buying it for at least its value in its alternative use. In this sense, non-integration gives the upstream party more recourse should the downstream party renege on the promised bonus. But non-integration has a drawback: it creates an incentive for the upstream party to increase the value of the good in its alternative use, in order to improve her bargaining position with the downstream party. These two conflicting effects (recourse and bargaining position) produce our main proposition: integration affects the parties' temptations to renege on a relational contract, and hence affects the best relational contract the parties can sustain.

Our proposition leads to an interesting corollary: in our model, it is impossible for a firm to mimic the spot-market outcome after it brings a transaction inside the firm, because the reneging temptation is then too great. This corollary is a first step towards a formal underpinning for Williamson's [1985: 135] observation that "selective intervention" must be impossible: if firms could mimic markets, intervening only when the market outcome would be inefficient, then we would observe one enormous firm. This corollary is also a cautionary tale for those who would "bring the market inside the firm" via empowerment, transfer pricing, performance measurement (such as "Economic Value Added"), and the like; we expand on this in Baker, Gibbons, and Murphy [2001].

We establish our main proposition and its corollary in Section III. In Section IV we explore the implications of our main proposition by deriving five further results. Our first result is that vertical integration is an efficient response to widely varying supply prices, because integration reduces reneging temptations in such situations. Our second result is that highpowered incentives create bigger reneging temptations under integration than under nonintegration, with the consequence that performance payments in relational incentive contracts will be smaller in firms than in (otherwise equivalent) markets. Although our first two results are driven by differences in reneging temptations under relational contracts, qualitatively similar results arise in a static analysis of our model, and in other static models in the tradition of Grossman and Hart. Our third, fourth, and fifth results, however, emphasize unique aspects of our repeated-game approach. Our third result is that, holding all other parameters constant, the optimal integration decision can depend on the discount rate. Our fourth result is that, holding 
all marginal incentives constant (and hence holding constant the optimal integration decision in the static model), the optimal integration decision can depend on the payoff levels. Finally, our fifth result extends the corollary in Section III: to complement the corollary that a firm cannot mimic the spot-market outcome, we show that a firm may be unable to improve upon even a mediocre spot-market outcome because the availability of the spot-market outcome as a fallback after reneging may render infeasible any desirable relational-employment contract.

Section V concludes by discussing four additional ideas. First, we describe how our approach relates to the extensive sociological literature on the formal and informal aspects of organizational structure. Second, we suggest how our approach might be applied to understanding organizational forms other than firms, such as joint ventures, strategic alliances, and business groups. Third, we explore the implications of our analysis for internal organizational processes such as transfer pricing, capital allocation, compensation, and corporate governance. Finally, we argue that our focus on relational contracts suggests a natural role for managers in the economic theory of the firm: managers formulate, communicate, implement, and change relational contracts. Such management can be as important in relationships between firms as within.

\section{ECONOMic ENVIRONMENT}

We consider an economic environment consisting of an upstream party, a downstream party, and an asset. Both parties and the asset live forever (or die together at a random date, as per the usual interpretation of "infinitely" repeated games). Both parties are risk-neutral and share the interest rate $\mathrm{r}$ per period. Initially, the downstream party owns the asset.

In each period, the upstream party may use the asset to produce a good. The downstream party values the good, but the good also has an alternative use. We assume that the good's value to the downstream party always exceeds its value in the alternative use. (For example, there might be other similar downstream parties but the asset might be tailored to this downstream party's needs. Alternatively, the upstream party might be able to set up shop as a downstream party, but lack the expertise to do so efficiently.) Regardless of how the good is used, its value falls to zero at the end of the period in which it was produced.

Ownership of the asset conveys ownership of the good produced using the asset. That is, if the downstream party owns the asset then he could simply take the good, refusing to pay the upstream party anything, whereas if the upstream party owns the asset then she could consign 
the good to its alternative use, paying no heed to objections from the downstream party. ${ }^{6}$ Of course, the latter scenario will not occur: because the value of the good to the downstream party exceeds its value in its alternative use, the efficient outcome when the upstream party owns the asset is for the parties to trade, exchanging money for the good.

Each period, the upstream party chooses a vector of $n$ actions $\mathbf{a}=\left(\mathrm{a}_{1}, \mathrm{a}_{2}, \ldots, \mathrm{a}_{\mathrm{n}}\right)$ at cost $\mathrm{c}(\mathbf{a})$. The actions in a given period affect both the downstream value (Q) and alternative-use value (P) of the good in that period. In particular, the downstream value is either high or low $\left(\mathrm{Q}_{\mathrm{H}}\right.$ or $\left.\mathrm{Q}_{\mathrm{L}}\right)$, the alternative-use value is either high or low $\left(\mathrm{P}_{\mathrm{H}}\right.$ or $\mathrm{P}_{\mathrm{L}}$, where $\left.\mathrm{P}_{\mathrm{L}}<\mathrm{P}_{\mathrm{H}}<\mathrm{Q}_{\mathrm{L}}<\mathrm{Q}_{\mathrm{H}}\right)$, and the upstream party's actions affect the probabilities that high values will be realized:

$$
\begin{aligned}
& \mathrm{Q}=\left\{\begin{array}{lll}
\mathrm{Q}_{\mathrm{H}} & \text { withprobability } & \mathrm{q}(\mathrm{a}) \\
\mathrm{Q}_{\mathrm{L}} & \text { with probability } & 1-\mathrm{q}(\mathrm{a})
\end{array}\right. \\
& \mathrm{P}=\left\{\begin{array}{lll}
\mathrm{P}_{\mathrm{H}} & \text { withprobability } & \mathrm{p}(\mathrm{a}) \\
\mathrm{P}_{\mathrm{L}} & \text { with probability } & 1-\mathrm{p}(\mathrm{a})
\end{array}\right.
\end{aligned} .
$$

Given the upstream party's actions, the downstream and alternative-use values are conditionally independent. We assume that $\mathrm{c}(0)=0, \mathrm{q}(0)=0$, and $\mathrm{p}(0)=0$, so that when the upstream party fails to take any actions, she bears no costs but also has no chance of realizing the high outcomes $\mathrm{Q}_{\mathrm{H}}$ or $\mathrm{P}_{\mathrm{H}}$. We write $\Delta \mathrm{Q} \equiv \mathrm{Q}_{\mathrm{H}}-\mathrm{Q}_{\mathrm{L}}$ and $\Delta \mathrm{P} \equiv \mathrm{P}_{\mathrm{H}}-\mathrm{P}_{\mathrm{L}}$.

The first-best actions, $\mathbf{a}^{*}$, maximize the expected value of the good in its efficient use minus the cost of actions, $\mathrm{Q}_{\mathrm{L}}+\mathrm{q}(\mathbf{a}) \Delta \mathrm{Q}-\mathrm{c}(\mathbf{a})$, and so produce total surplus

$$
\mathrm{S}^{*} \equiv \mathrm{Q}_{\mathrm{L}}+\mathrm{q}\left(\mathbf{a}^{*}\right) \Delta \mathrm{Q}-\mathrm{c}\left(\mathbf{a}^{*}\right) .
$$

The actions are unobservable to anyone but the upstream party, so contracts contingent on actions cannot be enforced. Achieving the first-best would still be possible if contracts dependent on Q could be enforced, but we assume that a contract that depends on the realized value of $\mathrm{Q}$ or $\mathrm{P}$ cannot be enforced by a third party. ${ }^{7}$ On the other hand, both $\mathrm{Q}$ and $\mathrm{P}$ can be

6. As this discussion makes clear, the "asset" in our model could simply be legal title to the good. Similarly, one could interpret our asset-ownership model in terms of alternative contracts between nonintegrated parties, where "downstream asset ownership" corresponds to a specific-performance contract that requires the upstream party to deliver the good to the downstream party and "upstream asset ownership" corresponds to the absence of a contract. We thank a referee for noting this contracting reinterpretation and for suggesting Maskin and Tirole [1999] for further remarks about the analogies between asset-ownership models and contracting models.

7. As in most of the incomplete-contracts literature, we acknowledge but do not model the role for formal contracts. That is, we interpret $\mathrm{Q}$ and $\mathrm{P}$ as representing the noncontractible elements of the exchange between the upstream and downstream parties, and assume that the contractible (i.e., observable and verifiable) elements are covered through formal contracts. As an illustration of the potential importance of relational contracts even 
observed by the upstream and downstream parties, so there are two potential ways to influence the upstream party's choice of actions: asset ownership and relational contracts. That is, if the upstream party owns the asset, she can negotiate with the downstream party over the price of the good. Alternatively, independent of who owns the asset, the realized values of Q and P can form the basis of a relational contract sustained by the value of future relationships.

We follow Grossman and Hart in interpreting asset ownership as integration, but our multi-task economic environment is closer in spirit to Holmstrom and Milgrom [1991], Holmstrom and Tirole [1991], and especially Holmstrom [1999], except that these multi-task models are static and hence analyze formal rather than relational contracts. As an illustration of our environment, consider the following two-dimensional linear example: the vector of actions has two components, $\mathbf{a}=\left(\mathrm{a}_{1}, \mathrm{a}_{2}\right)$, and the production functions $\mathrm{q}(\mathbf{a})$ and $\mathrm{p}(\mathbf{a})$ are

$$
\begin{aligned}
& \mathrm{q}(\mathbf{a})=\mathrm{q}_{1} \mathrm{a}_{1}+\mathrm{q}_{2} \mathrm{a}_{2} \text {, and } \\
& \mathrm{p}(\mathbf{a})=\mathrm{p}_{1} \mathrm{a}_{1}+\mathrm{p}_{2} \mathrm{a}_{2},
\end{aligned}
$$

where $\mathrm{q}_{1}, \mathrm{q}_{2}, \mathrm{p}_{1}, \mathrm{p}_{2} \geq 0$. This example nests two standard cases: (1) one-dimensional effort $\left(\mathrm{q}_{2}=\right.$ $\left.\mathrm{p}_{2}=0\right)$, where attempts to increase the probability of realizing the high alternative-use value $\left(\mathrm{P}_{\mathrm{H}}\right)$ also increase the probability of the high downstream value $\left(\mathrm{Q}_{\mathrm{H}}\right)$, and (2) unproductive multitasking $\left(\mathrm{q}_{2}=\mathrm{p}_{1}=0\right)$, where attempts to influence $\mathrm{P}$ are costly but have no effect on $\mathrm{Q}$, and so strictly reduce social surplus. Other values of $\mathrm{q}_{1}, \mathrm{q}_{2}, \mathrm{p}_{1}$, and $\mathrm{p}_{2}$ capture cases such as academics, where research contributes to internal and external productivity $\left(\mathrm{q}_{1}, \mathrm{p}_{1}>0\right)$ but administration contributes only to internal value $\left(\mathrm{q}_{2}>\mathrm{p}_{2}=0\right)$. Section III analyzes our general environment; Section IV focuses on this two-dimensional linear example.

Figure I summarizes the four combinations of asset ownership (upstream or downstream) and governance regimes (spot or relational) that are feasible in this environment. Consistent with common usage, we refer to the vertically integrated case as "employment," and the nonintegrated case as "outsourcing." We therefore call the four governance structures in Figure I "Spot Outsourcing" (where the upstream party owns the asset but there is no relational contract), "Spot Employment" (where the downstream party owns the asset but there is no relational contract), "Relational Employment" (where the downstream party owns the asset and there is a relational contract), and "Relational Outsourcing" (where the upstream party owns the asset and there is a relational contract).

in the presence of formal contracts, see Blumenstein and Stern [1996] on how the 1700-page contract between General Motors and the United Auto Workers has important gaps that are covered by informal agreements. But note that our suppression of the formal contracts in our analysis ignores potential interactions between the noncontractible and contractible elements of exchange; see Baker, Gibbons, and Murphy [1994], Bernheim and Whinston [1998], and Che and Yoo (forthcoming) for analyses of such interactions. 
Several of the classic contributions to organizational economics can be described using Figure I. For example, static analyses of integration in the absence of relational contracting [e.g., Grossman and Hart, 1986] are analogous to our comparison of spot outsourcing to spot employment (the top row in Figure I). Similarly, repeated-game analyses of relationships within firms [e.g., Bull, 1987] are analogous to our comparison of spot employment to relational employment (the right column) and repeated-game analyses of relationships between firms [e.g., Klein and Leffler, 1981] are analogous to our comparison of spot outsourcing to relational outsourcing (the left column). Finally, Williamson [1975, Chapters 4 and 5] emphasized that the advantage of firms over markets lies in the firm's ability to enforce relational contracts, which is analogous to our comparison of spot outsourcing to relational employment (the main diagonal).

The central focus of this paper is the comparison of relational outsourcing to relational employment (the bottom row of Figure I). Two important precursors to our analysis are Klein and Williamson. Both begin by arguing that court-enforceable explicit contracts between firms are typically incomplete, but each then focuses on half the story we wish to tell. Klein emphasizes that under non-integration relational contracts between firms often supplement incomplete explicit contracts and a shock may cause one of the firms to renege on the relational contract by enforcing the terms of the explicit contract (Klein, Crawford, and Alchian [1978], Klein [1996, 2000], and Klein and Murphy [1988, 1997]). But Klein is virtually silent about life under integration, except to argue that there will not be an explicit contract inside a firm so reneging by enforcing the terms of an explicit contract will not be possible. In contrast, Williamson [1975] built on Simon [1951] to emphasize the importance of relational contracts within firms, but was virtually silent about relational contracts between firms. Subsequently, Williamson [1985, Chapter 3] built on Macneil [1978] to incorporate relational contracts between firms into his framework; in our view, however, this extension allowed for the existence of relational forms of non-integration but hardly explored their limits or advantages relative to relational contracts within firms. ${ }^{8}$

Our model attempts an even-handed and formal analysis of relational contracts both within and between firms. Compared to Klein's argument, our model emphasizes not only that

8. Williamson's [1985] main comment about relational contracts between firms was to construe the resulting "hybrid" organizational forms as lying on a continuum between markets and hierarchies (p. 83), and Williamson [1996, Chapter 4] offers a deeper analysis in this spirit. But our Figure I suggests that the set of alternative governance structures is two-dimensional, so it is not possible to locate all governance structures on a line between markets and hierarchies. In this sense, our Figure I is consistent with the large sociological literature beginning with Powell [1990] that argues that networks and other relational forms of non-integration are not simply "hybrid" combinations of markets and hierarchies. 
integration eliminates one important reneging temptation present under non-integration but also that integration creates its own reneging temptation. Compared to Williamson's [1975] argument, our analysis of the reneging temptation under integration adds an important dimension to Williamson's [1975, Chapter 7; 1985, Chapter 6] discussions of the limitations of integrated governance. Finally, compared to both Klein and Williamson, our formal model derives several key concepts that they treat in reduced form, such as the size of the reneging temptations under non-integration and integration and the level of "relational capital" that each party could lose if it reneged.

\section{Outsourcing and Employment under Spot and Relational Governance}

In this section we analyze the four governance structures defined in Figure I. These four separate analyses allow us to derive our main proposition that asset ownership affects reneging temptations in relational contracts. ${ }^{9}$ We then conduct a comparative analysis in Section IV.

\section{A. Spot Outsourcing}

We first consider spot outsourcing. Once the actions are taken and the good is produced, the upstream party either sells the good to the downstream party or puts the good to its alternative use. Although upstream and downstream cannot contract directly on the realized values of Q and P, they can negotiate over the price of the good. We use the Nash bargaining solution (with equal bargaining powers) to arrive at this price: downstream will pay upstream the alternative-use value, $P_{j}$, plus half of the surplus from use by the downstream party, $Q_{i}-P_{j}$, so the price is $\frac{1}{2}\left(Q_{i}+P_{j}\right)$, where $i=H, L$ and $j=H, L$.

The upstream party's payoff under spot outsourcing is the price $\frac{1}{2}\left(\mathrm{Q}_{\mathrm{i}}+\mathrm{P}_{\mathrm{j}}\right)$ less the cost of actions c(a). Upstream therefore chooses actions $\mathbf{a}^{\mathrm{SO}}$ to solve

$$
\underset{\mathrm{a}}{\operatorname{MAX}} \frac{1}{2}\left[\mathrm{Q}_{\mathrm{L}}+\mathrm{q}(\mathbf{a}) \Delta \mathrm{Q}\right]+\frac{1}{2}\left[\mathrm{P}_{\mathrm{L}}+\mathrm{p}(\mathbf{a}) \Delta \mathrm{P}\right]-\mathrm{c}(\mathbf{a}) \equiv \mathrm{U}^{\mathrm{SO}} .
$$

The spot-outsourcing actions are thus likely to differ from the first-best actions. For example,

9. Garvey [1995] and Halonen [1994] also explore the effect of asset ownership on relational contracting, akin to our models of relational outsourcing and relational employment. Both Garvey and Halonen analyze repeated versions of the original Grossman-Hart model, whereas our static model captures a rich variety of multi-task settings. Also, Halonen assumes that ownership is fixed forever, even after reneging on the relational contract, whereas Garvey and we assume that ownership after reneging reverts to the efficient ownership at that point (with an appropriate transfer payment between parties). Finally, Garvey and Halonen do not present the results or interpretations we offer in Sections 3, 4, and 5. 
consider the extreme case when $\Delta \mathrm{Q}=0$ : the downstream party cannot benefit from effort, so the first-best levels of effort are all zero, but the upstream party will expend effort because $\mathrm{P}_{j}$ influences the price of the good under Nash bargaining. More generally, even when $\Delta \mathrm{Q}$ and $\Delta \mathrm{P}$ are positive, the upstream party may choose the wrong actions-exerting effort on activities that increase $\mathrm{P}$ even if they have no effect on $\mathrm{Q} .{ }^{10}$

After $\mathrm{Q}_{\mathrm{i}}$ and $\mathrm{P}_{\mathrm{j}}$ are realized and trade occurs, the downstream party's total payoff is $\mathrm{Q}_{\mathrm{i}}$ $\frac{1}{2}\left(\mathrm{Q}_{\mathrm{i}}+\mathrm{P}_{\mathrm{j}}\right)=\frac{1}{2}\left(\mathrm{Q}_{\mathrm{i}}-\mathrm{P}_{\mathrm{j}}\right)$. Define $\mathrm{D}^{\mathrm{SO}} \equiv \frac{1}{2} \mathrm{E}\left[\mathrm{Q}_{\mathrm{i}}-\mathrm{P}_{\mathrm{j}} \mid \mathbf{a}=\mathbf{a}^{\mathrm{SO}}\right]$ as downstream's expected payoff under spot outsourcing, conditional on upstream's optimal action choices. The total surplus under spot outsourcing is therefore

$$
\mathrm{S}^{\mathrm{SO}} \equiv \mathrm{D}^{\mathrm{SO}}+\mathrm{U}^{\mathrm{SO}}=\mathrm{Q}_{\mathrm{L}}+\mathrm{q}\left(\mathbf{a}^{\mathrm{SO}}\right) \Delta \mathrm{Q}-\mathrm{c}\left(\mathbf{a}^{\mathrm{SO}}\right) .
$$

\section{B. Spot Employment}

When the downstream party owns the asset but there is no relational contract, the downstream party can simply take the output without paying the upstream party. In anticipation of this outcome, the upstream party will refuse to take any costly actions, so the downstream value of the output will be $\mathrm{Q}_{\mathrm{L}}$ with certainty. Thus, the total surplus from spot employment is $\mathrm{S}^{\mathrm{SE}}=\mathrm{Q}_{\mathrm{L}}$, which can again be divided into upstream and downstream components, $\mathrm{U}^{\mathrm{SE}}+\mathrm{D}^{\mathrm{SE}} \equiv$ $\mathrm{S}^{\mathrm{SE}}$. Although we defer our main discussion of the comparative efficiency of spot outsourcing and spot employment until Section IV, we note here that spot employment dominates spot outsourcing only when the net benefit from upstream actions under spot governance is negative, $\mathrm{q}\left(\mathbf{a}^{\mathrm{SO}}\right) \Delta \mathrm{Q}-\mathrm{c}\left(\mathbf{a}^{\mathrm{SO}}\right)<0$. This could occur, for example, when the actions that affect the alternative-use value, $\mathrm{P}$, are unproductive or even counter-productive to the downstream value $\mathrm{Q}$, yet under spot outsourcing these actions are undertaken by the upstream party to improve her bargaining position.

Our model of spot employment may seem trivial and unrealistic: the upstream party refuses to take any actions whatsoever with respect to the noncontractible elements of exchange. But recall that we have ignored the possibility of formal contracts. One could add formal contracts and generate situations in which spot employment induces positive (although generally not first-best) effort. We do so in Baker, Gibbons, and Murphy [2001], but in this

10. Our model illustrates an important distinction in the literature concerning underinvestment in specific assets. Asset specificity is usually measured in terms of the levels of asset values (for example, $\mathrm{Q}_{\mathrm{L}}-\mathrm{P}_{\mathrm{H}}>0$ might be used as a measure of asset specificity in our model), whereas investment decisions are determined by margins (here $\Delta \mathrm{P}$ and $\Delta \mathrm{Q}$ ). Hence, assets can be very specific $\left(\mathrm{Q}_{\mathrm{L}}>\mathrm{P}_{\mathrm{H}}\right)$ and yet induce over-investment (if $\Delta \mathrm{P}$ $>\Delta \mathrm{Q}$ ). This point is obscured in models that tie asset levels to marginal returns in such a way that asset specificity necessarily produces under-investment. 
paper we omit such formal contracts in order to focus on relational contracts.

\section{Relational Employment}

In relational employment, as in spot employment, the downstream party owns the asset. But in relational employment (like Simon's [1951] employment relationships) there is also a relational contract based on the observable but noncontractible realizations $\mathrm{Q}$ and $\mathrm{P}$. We follow Bull [1987] in constructing a repeated-game model of such a relational contract between employer and employee. Unlike the spot-employment case, the relational-employment contract may provide upstream incentives, even though the downstream party owns the asset, provided that the parties value their reputations sufficiently. The core of the analysis is therefore checking whether reputation concerns in fact outweigh the temptation to renege on a given relational contract.

An important part of this calculation is the payoff after reneging. We analyze triggerstrategy equilibria, in which the party who did not renege refuses to enter into any new relational contract with the party who reneged. Because there are only two parties (one downstream and one upstream), this trigger-strategy assumption implies that the parties live under spot governance forever after one reneges. To determine whether such spot governance takes the form of a spot outsourcing or spot employment, we allow the parties to negotiate over asset ownership after reneging. Thus, the downstream party will retain ownership when $\mathrm{S}^{\mathrm{SE}}>\mathrm{S}^{\mathrm{SO}}$, but will sell the asset to the upstream party (at some price $\pi$ ) when $\mathrm{S}^{\mathrm{SO}}>\mathrm{S}^{\mathrm{SE}}$.

Consider the relational compensation contract $\left(\mathrm{s}, \mathrm{b}_{\mathrm{HH}}, \mathrm{b}_{\mathrm{HL}}, \mathrm{b}_{\mathrm{LH}}, \mathrm{b}_{\mathrm{LL}}\right) \equiv\left(\mathrm{s},\left\{\mathrm{b}_{\mathrm{ij}}\right\}\right)$, where salary $\mathrm{s}$ is paid by downstream to upstream at the beginning of each period and $b_{i j}$ is supposed to be paid when $\mathrm{Q}=\mathrm{Q}_{\mathrm{i}}$ and $\mathrm{P}=\mathrm{P}_{\mathrm{j}}$, respectively (for $\mathrm{i}, \mathrm{j}=\mathrm{H}, \mathrm{L}$ ). For the moment, suppose that the upstream party is confident that the downstream party will indeed pay $b_{i j}$ as promised (and that the upstream party will make any promised payments if $b_{i j}<0$ ). If the upstream party accepts the contract, she will choose a vector of actions $\mathbf{a}^{\mathrm{RE}}$ to solve

$$
\underset{\mathrm{a}}{\operatorname{MAX}} \mathrm{s}+\mathrm{b}_{\mathrm{LL}}(1-\mathrm{q})(1-\mathrm{p})+\mathrm{b}_{\mathrm{HL}} \mathrm{q}(1-\mathrm{p})+\mathrm{b}_{\mathrm{LH}}(1-\mathrm{q}) \mathrm{p}+\mathrm{b}_{\mathrm{HH}} \mathrm{qp}-\mathrm{c}(\mathbf{a}) \equiv \mathrm{U}^{\mathrm{RE}}
$$

where $\mathrm{q} \equiv \mathrm{q}(\mathbf{a})$ and $\mathrm{p} \equiv \mathrm{p}(\mathbf{a})$. The expected downstream payoff is then

$$
\mathrm{E}\left[\mathrm{Q}_{\mathrm{i}}-\mathrm{s}-\mathrm{b}_{\mathrm{ij}} \mid \mathbf{a}=\mathbf{a}^{\mathrm{RE}}\right]=\mathrm{Q}_{\mathrm{L}}+\Delta \mathrm{Q} \mathrm{q}\left(\mathbf{a}^{\mathrm{RE}}\right)-\left[\mathrm{U}^{\mathrm{RE}}+\mathrm{c}\left(\mathbf{a}^{\mathrm{RE}}\right)\right] \equiv \mathrm{D}^{\mathrm{RE}} \text {, }
$$

so the total surplus generated under relational employment is

$$
\mathrm{S}^{\mathrm{RE}} \equiv \mathrm{U}^{\mathrm{RE}}+\mathrm{D}^{\mathrm{RE}}=\mathrm{Q}_{\mathrm{L}}+\mathrm{q}\left(\mathbf{a}^{\mathrm{RE}}\right) \Delta \mathrm{Q}-\mathrm{c}\left(\mathbf{a}^{\mathrm{RE}}\right) .
$$

The relational-employment contract $\left(s,\left\{b_{i j}\right\}\right)$ is self-enforcing if both parties choose to honor the contract for all possible realizations of $Q_{i}$ and $P_{j}$. The downstream party reneges if he 
refuses to pay the promised bonus $b_{\mathrm{ij}}$ to the upstream party, instead simply taking the good and paying nothing. After reneging, the downstream party will either retain ownership and earn the spot-employment payoff $\mathrm{D}^{\mathrm{SE}}=\mathrm{Q}_{\mathrm{L}}$ in perpetuity (when $\mathrm{S}^{\mathrm{SE}}>\mathrm{S}^{\mathrm{SO}}$ ), or sell the asset upstream for $\pi$ and earn spot-outsourcing payoff $\mathrm{D}^{\mathrm{SO}}$ in perpetuity (when $\mathrm{S}^{\mathrm{SO}}>\mathrm{S}^{\mathrm{SE}}$ ).

Assume first that $\mathrm{S}^{\mathrm{SE}}>\mathrm{S}^{\mathrm{SO}}$, so that if reneging occurs then the downstream party will retain ownership and earn $\mathrm{D}^{\mathrm{SE}}$ in perpetuity. The downstream party will honor the relationalemployment contract as long as the present value of honoring the contract exceeds the present value of reneging. Since the present value of honoring the contract is $-b_{i j}+1 / r D^{R E}$, the downstream owner will honor rather than renege on the relational contract when, for all $\mathrm{i}$ and $\mathrm{j}$,

$$
-b_{i j}+\frac{1}{r} D^{R E} \geq \frac{1}{r} D^{S E} .
$$

The upstream party reneges on the relational-employment contract by refusing to accept a promised payment $b_{i j}$ when it was offered (or by refusing to make a promised payment if $b_{i j}<$ 0 ), earning $\mathrm{U}^{\mathrm{SE}}$ thereafter. Thus, the upstream party will honor rather than renege on the relational contract when, for all $\mathrm{i}$ and $\mathrm{j}$,

$$
\mathrm{b}_{\mathrm{ij}}+\frac{1}{\mathrm{r}} \mathrm{U}^{\mathrm{RE}} \geq \frac{1}{\mathrm{r}} \mathrm{U}^{\mathrm{SE}} .
$$

If (6) holds for all $i$ and $j$ then it must hold for the largest $b_{i j}$, while if (7) holds for all $i$ and $\mathrm{j}$ it must hold for the smallest $\mathrm{b}_{\mathrm{ij}}$. Combining these two extreme versions of (6) and (7) yields a necessary condition for the relational-employment contract $\left(s,\left\{b_{i j}\right\}\right)$ to be self-enforcing when $\mathrm{S}^{\mathrm{SE}}>\mathrm{S}^{\mathrm{SO}}$ :

$$
\max b_{i j}-\min b_{i j} \leq \frac{1}{r}\left(S^{R E}-S^{S E}\right) .
$$

Next assume that $S^{S O}>S^{S E}$, so that if reneging occurs then the upstream party will purchase the ownership right from the downstream party for some price $\pi$, after which the upstream and downstream parties earn $\mathrm{U}^{\mathrm{SO}}$ and $\mathrm{D}^{\mathrm{SO}}$, respectively. In this case, the righthand side of (6) becomes $1 / \mathrm{D}^{\mathrm{SO}}+\pi$, and the righthand side of (7) becomes $1 / \mathrm{r} \mathrm{U}^{\mathrm{SO}}-\pi$, so combining the extreme versions of the resulting incentive constraints yields a necessary condition for the relational-employment contract $\left(s,\left\{b_{i j}\right\}\right)$ to be self-enforcing when $S^{S O}>S^{S E}$ :

$$
\max b_{i j}-\min b_{i j} \leq \frac{1}{r}\left(S^{R E}-S^{S O}\right) .
$$

Combining (8) and (9) yields a single necessary condition for a self-enforcing relationalemployment contract: 


$$
\max b_{i j}-\min b_{i j} \leq \frac{1}{r}\left(S^{R E}-\max \left(S^{S E}, S^{S O}\right)\right) .
$$

In fact, (10) is sufficient as well as necessary, because for any max $b_{i j}$ and $\min b_{i j}$ satisfying (10), a fixed payment, s, can always be chosen that satisfies (6) and (7) (when $\mathrm{S}^{\mathrm{SE}}>\mathrm{S}^{\mathrm{SO}}$ ) or their analogs (when $S^{S O}>S^{S E}$ ). The left-hand side of (10) is the maximum total temptation to renege on the relational-employment contract (i.e., the upstream party's temptation plus the downstream's). The right-hand side is the present value of the net total surplus (i.e., the total surplus from continuing the relationship, $S^{R E}$, less the best fallback if either party should renege, $\left.\max \left[\mathrm{S}^{\mathrm{SO}}, \mathrm{S}^{\mathrm{SE}}\right]\right)$. The efficient relational-employment contract maximizes the total surplus $S^{\mathrm{RE}}$ in (5), subject to the feasibility constraint (10). ${ }^{11}$

Given functional forms for $\mathrm{q}(\mathbf{a})$ and $\mathrm{p}(\mathbf{a})$ and values for the parameters $\Delta \mathrm{Q}, \Delta \mathrm{P}$, and $\mathrm{r}$, we could now determine whether (i) relational employment can achieve first-best upstream actions, (ii) relational employment can exist (i.e., there exist payments and associated actions satisfying (4) and (10) that produce higher total surplus than spot employment) but cannot achieve the first-best, or (iii) relational employment cannot exist (i.e., the payments and actions from spot employment are the only solution to (4) and (10)). We do not pause here to explore these three possibilities because for many functional-form assumptions and parameter values some other organizational form (i.e., spot outsourcing, relational outsourcing, or spot employment) will be more efficient; see below.

\section{Relational Outsourcing}

We next consider relational outsourcing-relational contracts where the upstream party owns the asset. Such relational contracts in non-integrated supply transactions have been analyzed at least since Klein and Leffler [1981] and Telser [1981], but there has been no formal comparison of these Klein-Leffler-Telser-style models of relationships between firms to the Bull-Simon-style models of relationships within firms. We show that relational contracts between non-integrated parties (outsourcing) differ from those between integrated parties (employment) in the ways they tempt each party to renege.

If the promised payment $b_{\mathrm{ij}}$ is greater than the price that would be negotiated under spot outsourcing, $\frac{1}{2}\left(Q_{i}+P_{j}\right)$, the downstream purchaser would be better off this period if he

11. Note that the same derivation would hold for arbitrary finite sets of possible realizations for $\mathrm{Q}$ and $\mathrm{P}: \mathrm{Q}$ $\in\left\{\mathrm{Q}_{1}, \ldots, \mathrm{Q}_{\mathrm{I}}\right\}$ and $\mathrm{P} \in\left\{\mathrm{P}_{1}, \ldots, \mathrm{P}_{\mathrm{J}}\right\}$, where $\mathrm{Q}_{1}>\ldots>\mathrm{Q}_{\mathrm{I}}>\mathrm{P}_{1}>\ldots>\mathrm{P}_{\mathrm{J}}$. In fact, the derivation persists even without all the possible realizations of $\mathrm{Q}$ being above all those of $\mathrm{P}$, as long as the joint distribution of $\mathrm{Q}$ and $\mathrm{P}$ puts positive probability on $\left(\mathrm{Q}_{\mathrm{i}}, \mathrm{P}_{\mathrm{j}}\right)$ only if $\mathrm{Q}_{\mathrm{i}}>\mathrm{P}_{\mathrm{j}}$. The fact that the many constraints in (6) and (7) reduce to the single constraint in (8), and likewise in deriving (9), is well known in the literature; see MacLeod and Malcolmson [1989, 1998] and Levin [2000]. The appearance of the maximum total reneging temptation on the lefthand sides of (8) and (9) also is familiar, and leads to Levin's result on "bang-bang" contracts. 
reneged on the relational-outsourcing contract. Similarly, if the promised payment $b_{i j}$ is less than $\frac{1}{2}\left(Q_{i}+P_{j}\right)$ then the upstream producer would be better off this period if she reneged. Thus, a key difference between relational contracts under outsourcing versus under employment is that the good's value in its alternative use, $\mathrm{P}_{\mathrm{j}}$, affects the reneging decision under relational outsourcing but not under relational employment. This difference drives our main Proposition and several of our subsequent results.

The analysis of relational outsourcing parallels that of relational employment. If the upstream party is confident that the downstream party will honor the contract $\left(s,\left\{b_{i j}\right\}\right)$ then the upstream party will choose a vector of actions $\mathbf{a}^{\mathrm{RO}}$ to solve

$$
\underset{\mathrm{a}}{\operatorname{MAX}} \mathrm{s}+\mathrm{b}_{\mathrm{LL}}(1-\mathrm{q})(1-\mathrm{p})+\mathrm{b}_{\mathrm{HL}} \mathrm{q}(1-\mathrm{p})+\mathrm{b}_{\mathrm{LH}}(1-\mathrm{q}) \mathrm{p}+\mathrm{b}_{\mathrm{HH}} \mathrm{qp}-\mathrm{c}(\mathbf{a}) \equiv \mathrm{U}^{\mathrm{RO}},
$$

where $\mathrm{q} \equiv \mathrm{q}(\mathbf{a})$ and $\mathrm{p} \equiv \mathrm{p}(\mathbf{a})$. The expected downstream payoff is then $\mathrm{E}\left[\mathrm{Q}_{\mathrm{i}}-\mathrm{s}-\mathrm{b}_{\mathrm{ij}} \mid \mathbf{a}=\mathbf{a}^{\mathrm{RO}}\right] \equiv$ $\mathrm{D}^{\mathrm{RO}}$, so the total surplus under relational-outsourcing contract is

$$
\mathrm{S}^{\mathrm{RO}} \equiv \mathrm{U}^{\mathrm{RO}}+\mathrm{D}^{\mathrm{RO}}=\mathrm{Q}_{\mathrm{L}}+\mathrm{q}\left(\mathbf{a}^{\mathrm{RO}}\right) \Delta \mathrm{Q}-\mathrm{c}\left(\mathbf{a}^{\mathrm{RO}}\right) .
$$

Note that a given relational contract $\left(s,\left\{b_{i j}\right\}\right)$ produces the same actions and the same surplus under relational outsourcing as under relational employment (assuming that the relational contract satisfies the relevant reneging constraints in each case). But, as we show next, the temptation to renege on a relational employment contract differs from the temptation to renege under relational outsourcing.

Once $Q_{i}$ and $P_{j}$ have been realized, the downstream party is supposed to receive the net payoff $Q_{i}-b_{i j}$. If he reneges on the relational-outsourcing contract, he negotiates to buy the good for the spot-outsourcing price of $\frac{1}{2}\left(Q_{i}+P_{j}\right)$ instead of for $b_{i j}$, realizing a current payoff of $Q_{i}-\frac{1}{2}\left(Q_{i}+P_{j}\right)$. Likewise, once $Q_{i}$ and $P_{j}$ have been realized, the upstream party is supposed to the sell the good for the price $b_{i j}$. If she reneges, she negotiates to sell the good for the spot price of $\frac{1}{2}\left(Q_{i}+P_{j}\right)$.

Assume first that $\mathrm{S}^{\mathrm{SO}}>\mathrm{S}^{\mathrm{SE}}$, so that it is efficient for the upstream party to retain ownership of the asset after either party reneges on the relational contact. In this case, the downstream party will honor rather than renege on the relational contract when, for all $\mathrm{i}$ and $\mathrm{j}$,

$$
\begin{gathered}
Q_{i}-b_{i j}+\frac{1}{r} D^{R O} \geq \frac{1}{2}\left(Q_{i}-P_{j}\right)+\frac{1}{r} D^{S O}, \text { or } \\
b_{i j}-\frac{1}{2}\left(Q_{i}+P_{j}\right) \leq \frac{1}{r}\left(D^{R O}-D^{S O}\right) .
\end{gathered}
$$

Likewise, the upstream party will honor rather than renege on the relational-outsourcing contract when, for all $i$ and $j$,

$$
b_{i j}-\frac{1}{2}\left(Q_{i}+P_{j}\right) \geq \frac{1}{r}\left(U^{S O}-U^{R O}\right) .
$$


If (12) holds for all $i$ and $j$ then it must hold for the largest value of $b_{i j}-\frac{1}{2}\left(Q_{i}+P_{j}\right)$, while if (13) holds for all $i$ and $j$ it must hold for the smallest value of $b_{i j}-\frac{1}{2}\left(Q_{i}+P_{j}\right)$. Combining these two extreme versions of (12) and (13) yields a single necessary condition for the relational-outsourcing contract $\left(\mathrm{s},\left\{\mathrm{b}_{\mathrm{ij}}\right\}\right)$ to be self-enforcing when $\mathrm{S}^{\mathrm{SO}}>\mathrm{S}^{\mathrm{SE}}$ :

$$
\max \left(b_{i j}-\frac{1}{2}\left(Q_{i}+P_{j}\right)\right)-\min \left(b_{i j}-\frac{1}{2}\left(Q_{i}+P_{j}\right)\right) \leq \frac{1}{r}\left(S^{R O}-S^{S O}\right) .
$$

As in the analysis of relational employment, this necessary condition is also sufficient.

Next assume that $S^{S E}>S^{S O}$, so that it is efficient for the upstream party to sell the asset downstream at some price $\pi$ after either party reneges on the relational contact. In this case, the righthand side of (12) becomes $1 / r\left(D^{R O}-D^{S E}\right)-\pi$, and the righthand side of (13) becomes $1 / \mathrm{r}\left(\mathrm{U}^{\mathrm{SO}}-\mathrm{U}^{\mathrm{RE}}\right)+\pi$, so combining the extreme versions of the resulting incentive constraints yields a single necessary condition for the relational-outsourcing contract $\left(s,\left\{b_{i j}\right\}\right)$ to be selfenforcing when $\mathrm{S}^{\mathrm{SE}}>\mathrm{S}^{\mathrm{SO}}$ :

$$
\max \left(b_{i j}-\frac{1}{2}\left(Q_{i}+P_{j}\right)\right)-\min \left(b_{i j}-\frac{1}{2}\left(Q_{i}+P_{j}\right)\right) \leq \frac{1}{r}\left(S^{R O}-S^{S E}\right) .
$$

Combining (14) and (15) yields a single necessary condition for a self-enforcing relational-outsourcing contract:

$$
\max \left(b_{i j}-\frac{1}{2}\left(Q_{i}+P_{j}\right)\right)-\min \left(b_{i j}-\frac{1}{2}\left(Q_{i}+P_{j}\right)\right) \leq \frac{1}{r}\left(S^{R O}-\max \left[S^{S O}, S^{S E}\right]\right) .
$$

As in the analysis of relational employment, this necessary condition is also sufficient (and, as noted in the footnote below (10), the argument can be generalized to arbitrary finite sets of realizations for Q and P). Parallel to (10), the left-hand side of (16) is the maximum total temptation to renege on the relational-outsourcing contract and the right-hand side is the present value of the total surplus from continuing the relationship, $S^{R O}$, less the best fallback if either party should renege, $\max \left[\mathrm{S}^{\mathrm{SO}}, \mathrm{S}^{\mathrm{SE}}\right]$. The efficient relational-outsourcing contract maximizes the total surplus $S^{\mathrm{RO}}$ in (11), subject to the feasibility constraint (16).

Given functional forms for $\mathrm{q}(\mathbf{a})$ and $\mathrm{p}(\mathbf{a})$ and values for the parameters $\Delta \mathrm{Q}, \Delta \mathrm{P}$, and $\mathrm{r}$, we could again determine whether (i) relational outsourcing can achieve first-best upstream actions, (ii) relational outsourcing can exist but cannot achieve the first-best, or (iii) relational outsourcing cannot exist. We again defer our exploration of these possibilities.

We conclude this section by stating our main proposition and its corollary.

Proposition: Asset ownership affects the parties' temptations to renege on a relational contract, and hence affects whether a given relational contract is feasible. Formally, the relational contract $\left(\mathrm{s},\left\{\mathrm{b}_{\mathrm{ij}}\right\}\right)$ produces the same actions and total surplus under either ownership structure, but the maximum total reneging 
temptation is $\max \left(\mathrm{b}_{\mathrm{ij}}\right)-\min \left(\mathrm{b}_{\mathrm{ij}}\right)$ in (10) under relational employment versus $\max \left(b_{i j}-\frac{1}{2}\left(Q_{i}+P_{j}\right)\right)-\min \left(b_{i j}-\frac{1}{2}\left(Q_{i}+P_{j}\right)\right)$ in (16) under relational outsourcing.

The proposition reveals that whether the parties are integrated or non-integrated affects their temptations to renege on a given relational contract. In some situations, the reneging temptation is lower between integrated parties; in others, the reneging temptation is lower between non-integrated parties. This result motivates an under-explored perspective on vertical integration: a major factor in the vertical-integration decision is whether integration or nonintegration facilitates the superior relational contract.

Before beginning to explore the implications of this proposition in Section IV, we pause to compare it to some of the work discussed in connection with Figure I above. For example, consider Bull's model of a subjective bonus (or any other model of relational contracts within firms): the words describe an informal agreement within a firm, but could the model be reinterpreted as concerning a hand-in-glove supply relationship between two firms? Similarly, consider Klein and Leffler's model of a supply relationship (or any other model of relational contracts between firms): the words describe an informal agreement between firms, but could the model be reinterpreted as concerning transfer payments between upstream and downstream divisions of a single firm? In short, in a typical repeated-game model, it is unclear whether the relational contract is within or between firms, and consequently also unclear whether this distinction matters. By including asset ownership in our model, we both clarify this distinction and show that it does matter: asset ownership affects the parties' temptations to renege, and so affects what relational contracts are feasible and what asset ownership pattern is efficient. ${ }^{12}$

Our proposition can also be compared to Grossman and Hart's perspective on integration. Although we adopt their assumptions that bringing a transaction inside a firm does not create any additional information, or render formerly non-contractible outcomes contractible, or change the preferences of any actor, we depart from their assertion that "the benefits of integration must surely be more than the ability to choose a new payment method" (p. 694). In our model, one important benefit of integration is precisely the ability to choose a new payment method (i.e., a different relational contract).

12 Kreps's [1990] classic paper on corporate culture provides another example in this vein. Some readers have interpreted Kreps's analysis as within a firm (e.g., culture as a promise to employees), while others have interpreted the analysis as between firms (e.g., culture as a promise to suppliers or customers). Kreps is clearly correct that corporate culture is important to both internal and external constituencies, but our proposition implies that a single repeated-game model (i.e., a model without an asset-ownership variable or its equivalent) cannot simultaneously describe both of these important relational contracts. 
Finally, our main proposition produces the following corollary.

Corollary: It is impossible for a firm to mimic the spot-market outcome after it brings a transaction inside the firm because the reneging temptation is too great. Formally, the relational contract that replicates the payoffs of spot outsourcing - namely, $\left(\mathrm{s}=0,\left\{\mathrm{~b}_{\mathrm{ij}}=\frac{1}{2}\left(\mathrm{Q}_{\mathrm{i}}+\mathrm{P}_{\mathrm{j}}\right)\right\}\right)$ - of course produces the same actions and surplus as spot outsourcing, but fails to satisfy (10) because the maximum total reneging temptation under relational employment - namely, $\max \left(\mathrm{b}_{\mathrm{ij}}\right)$ $\min \left(\mathrm{b}_{\mathrm{ij}}\right)=\frac{1}{2}\left(\mathrm{Q}_{\mathrm{H}}+\mathrm{P}_{\mathrm{H}}\right)-\frac{1}{2}\left(\mathrm{Q}_{\mathrm{L}}+\mathrm{P}_{\mathrm{L}}\right)$ - is positive whereas the difference in surplus - namely, $\frac{1}{\mathrm{r}}\left(\mathrm{S}^{\mathrm{SO}}-\max \left[\mathrm{S}^{\mathrm{SO}}, \mathrm{S}^{\mathrm{SE}}\right]\right)$ - cannot exceed zero. ${ }^{13}$

If firms could write contracts with employees that provide incentives identical to those created in markets, then firms could try to mimic the market in cases where the market outcome is efficient but intervene in cases where the market outcome is inefficient. Williamson [1985: 135] argued that such "selective intervention" must be impossible, else we would observe one enormous firm. This corollary offers a first step towards formal support for Williamson's argument: relational employment contracts cannot replicate incentives from spot markets. We extend this corollary in Section IV by showing that the availability of inefficient spot outsourcing may prevent the existence of more efficient relational employment. That is, not only will a firm be unable to mimic the spot-market outcome after it brings a transaction inside the firm, it may also be unable to improve upon the spot-market outcome, because the relational contract necessary for such improvements has too great a reneging temptation when spotmarket governance is available after reneging.

\section{A Comparative Analysis of Organizational Forms}

The preceding section characterized upstream actions and total surplus under four alternative governance structures. In a given environment, the efficient organizational form maximizes the total surplus. For some parameter values, relational employment will be the efficient organizational form; for others, relational outsourcing will dominate; for still other parameters, neither relational outsourcing nor employment will be feasible and spot outsourcing or spot employment will dominate.

In this section we begin to explore the implications of our main proposition by deriving

13 Note that the reverse is also true: it is impossible under non-integration to mimic the spotemployment outcome after the transaction is brought outside the firm, because the reneging temptation is too great. 
five additional results. We emphasize that these additional results are exploratory and suggestive, in two senses. First, they are derived for specific functional forms rather than for the more general model in Section III. And second, they only begin to probe what we expect to be a broad set of applications of our main proposition, some of which we sketch in Section V.

In this section we also solve an example for which we compute and display the efficient organizational form as a function of parameters such as $\mathrm{r}, \Delta \mathrm{Q}$, and $\Delta \mathrm{P}$. That is, for this example, we conduct a formal version of the comparative analysis proposed by Coase [1937] and elaborated by Williamson [1975, 1985, 1996]: when will a given transaction occur within a single firm rather than between two? Relative to static versions of this formal comparison in the tradition of Grossman and Hart (such as Hart and Moore [1990] and Hart [1995]), our analysis encourages a richer conception of life within and between firms, by emphasizing the importance of relational contracts in both cases. Relative to informal comparisons of relational contracts within and between firms, such as Williamson [1996, Chapter 4], our analysis derives rather than assumes the "relational capital" and reneging temptations that are critical to this comparison.

Our first result is that vertical integration is an efficient response to widely varying supply prices (even when all parties are risk-neutral), because integration reduces reneging temptations in such settings. We show that under non-integrated ownership, an extreme realization of the supply price creates a large temptation to renege on a relational contract. This reneging temptation limits the incentive power of the best relational contract that can be implemented under non-integrated ownership. Under integrated ownership, however, we show that the reneging temptation is independent of the supply price, making integration the more efficient governance structure when the supply price can vary widely. As we discuss below, this result may help explain a puzzle noted by Carlton [1979]: why would risk-neutral companies pursue vertical mergers to achieve certainty of supply?

Our second result is that high-powered incentives create bigger reneging temptations under integration than under non-integration, with the consequence that performance payments in relational incentive contracts will be smaller under integration than under (otherwise equivalent) non-integration. In our repeated-game model, the downstream party promises the upstream party a bonus for delivering high quality. In the integrated case, the upstream employee has no recourse if the downstream firm refuses to pay the promised bonus; in the non-integrated case, however, if the upstream independent contractor is not paid a promised bonus, she can still extract some payment for the good through bargaining. Reneging on the bonus owed to an independent contractor thus saves only the amount of the bonus over and above the payment that would be determined by such bargaining. The downstream party's 
temptation not to pay the bonus is therefore smaller under non-integration than under integration. This reduced temptation makes it credible to promise a larger bonus payment to an independent contractor than to an employee.

Because $\mathrm{Q}$ and $\mathrm{P}$ are not contractible, the promised bonus $\mathrm{b}_{\mathrm{ij}}$ is not a court-enforceable contract, but the bonus payment might nonetheless be measurable by examining payroll records or the like. Our predicted difference in measurable bonus payments to independent contractors versus employees is thus potentially testable. In this sense, our second result can be seen as a testable version of Williamson's [1985, Ch. 6] observation that incentives are "higherpowered" in markets than in firms. That is, Williamson's observation seems to focus on total incentives (which may be difficult to measure), whereas our result matches Williamson's observation about total incentives but produces a prediction in terms of measurable bonus payments. In contrast, many static models in the Grossman-Hart tradition also match Williamson's observation about total incentives but generate this prediction from the effects of asset ownership on marginal incentives (which again seem hard to measure), without producing any prediction about the levels of measurable payments. Whinston (2000) develops a parallel critique of the testability of asset-ownership models by emphasizing the difference between measurable levels of asset specificity versus hard-to-measure marginal effects.

Our third result is that, holding all other parameters constant, the optimal integration decision can depend on the discount rate (which is of course irrelevant in a static model). At sufficiently low discount rates, ownership is irrelevant because the first-best can be achieved under either relational outsourcing or relational employment. But the relational contract that achieves the first-best has different maximum total reneging temptations under integration versus non-integration, so there is a critical discount rate at which it becomes impossible to achieve the first-best under one ownership structure but is still possible under the other. Thus, moving from low to moderate discount rates can change the optimal ownership structure. Similarly, we show that a slight increase in the discount rate can change the efficient organizational form from second-best relational employment to (spot or relational) outsourcing.

Our fourth result is that, holding all marginal incentives constant, the optimal integration decision can depend on the payoff levels (which play no separate role our in static model, if marginal incentives are held constant). For example, imagine increasing $\Delta \mathrm{P}$ but holding marginal incentives constant (by correspondingly decreasing another appropriate parameter) and suppose that these constant marginal incentives make spot outsourcing more efficient than spot employment. This increase in $\Delta \mathrm{P}$ increases the maximum total reneging temptation in relational outsourcing but not in relational employment (and the decrease in the other parameter has no effect on reneging temptations). As a result, relational employment may be feasible when 
relational outsourcing is not, reversing the conclusion of the static model.

Our fifth result extends the corollary in Section III, which showed that a firm will be unable to mimic the spot-market outcome after it brings a transaction inside the firm. We now show that a mediocre spot market may prevent the existence of any firm, including a firm that would be more efficient than the spot market. More precisely, a firm may be unable to improve upon the spot-market outcome because the availability of the spot-market outcome as a fallback after reneging may ruin any relational-employment contract that could improve on the spotmarket outcome. One interesting implication of this result is that a small change in parameters can force firms to abandon more efficient employment relationships in favor of less efficient outsourcing.

Our fifth result is in the spirit of the Coase-Williamson argument that a firm arises only if a spot market would perform sufficiently poorly, but our reasoning is new. In our model, the market may supplant a firm in governing a particular transaction not because the market wins the head-to-head competition between governance structures implicitly envisioned by Coase and Williamson, but rather because the existence of the market as a fallback after reneging may prevent the existence of the firm in the first place. This result again distinguishes our repeatedgame approach from existing static models, because in static models either there are no contracts (as in Grossman-Hart) or the feasible set of contracts does not depend on asset ownership (as in Holmstrom), whereas this result shows that the feasible set of relational contracts under one ownership structure depends on the desirability of changing asset ownership after reneging.

\section{A. Additional assumptions}

We prove these five results for a special case of the model developed in Section III. We assume henceforth that the vector of actions $\mathbf{a}$ has two components, the production functions $\mathrm{q}(\mathbf{a})$ and $\mathrm{p}(\mathbf{a})$ are linear, and the cost function $\mathrm{c}(\mathbf{a})$ is quadratic:

$$
\begin{aligned}
& \mathbf{a}=\left(\mathrm{a}_{1}, \mathrm{a}_{2}\right), \\
& \mathrm{q}(\mathbf{a})=\mathrm{q}_{1} \mathrm{a}_{1}+\mathrm{q}_{2} \mathrm{a}_{2}, \\
& \mathrm{p}(\mathbf{a})=\mathrm{p}_{1} \mathrm{a}_{1}+\mathrm{p}_{2} \mathrm{a}_{2}, \text { and } \\
& \mathrm{c}(\mathbf{a})=\frac{1}{2} \mathrm{a}_{1}^{2}+\frac{1}{2} \mathrm{a}_{2}^{2},
\end{aligned}
$$

where $\mathrm{q}_{1}, \mathrm{q}_{2}, \mathrm{p}_{1}, \mathrm{p}_{2} \geq 0$ and $\mathrm{q}_{1} \mathrm{p}_{2} \neq \mathrm{q}_{2} \mathrm{p}_{1}$. For this linear-quadratic case, the first-best actions are

$$
\mathrm{a}_{1}^{\mathrm{FB}}=\mathrm{q}_{1} \Delta \mathrm{Q} \quad \text { and } \mathrm{a}_{2}^{\mathrm{FB}}=\mathrm{q}_{2} \Delta \mathrm{Q} .
$$


In contrast, under spot outsourcing the upstream party chooses $a_{1}$ and $a_{2}$ to maximize $\frac{1}{2}\left(\mathrm{Q}_{\mathrm{L}}+\mathrm{P}_{\mathrm{L}}\right)+\frac{1}{2} \mathrm{q}(\mathbf{a}) \Delta \mathrm{Q}+\frac{1}{2} \mathrm{p}(\mathbf{a}) \Delta \mathrm{P}-\mathrm{c}(\mathbf{a})$, so

$$
\mathrm{a}_{1}{ }^{\mathrm{SO}}=\frac{1}{2} \mathrm{q}_{1} \Delta \mathrm{Q}+\frac{1}{2} \mathrm{p}_{1} \Delta \mathrm{P} \quad \text { and }
$$

$$
\mathrm{a}_{2}{ }^{\mathrm{SO}}=\frac{1}{2} \mathrm{q}_{2} \Delta \mathrm{Q}+\frac{1}{2} \mathrm{p}_{2} \Delta \mathrm{P} \text {. }
$$

And under spot employment the upstream party has no incentive to take costly actions and so chooses $\mathrm{a}_{1}{ }^{\mathrm{SE}}=\mathrm{a}_{2}^{\mathrm{SE}}=0$.

With some loss of generality but substantial gain in expositional efficiency, we also assume henceforth that the bonus payments $b_{i j}$ in any relational contract satisfy:

$$
\begin{array}{ll}
b_{\mathrm{HH}}=b_{\mathrm{H}}+\beta_{\mathrm{H}}, & b_{\mathrm{HL}}=b_{\mathrm{H}}+\beta_{\mathrm{L}}, \\
\mathrm{b}_{\mathrm{LH}}=\mathrm{b}_{\mathrm{L}}+\beta_{\mathrm{H}}, & \mathrm{b}_{\mathrm{LL}}=\mathrm{b}_{\mathrm{L}}+\beta_{\mathrm{L}} .
\end{array}
$$

This restriction on bonus payments amounts to assuming that the downstream party pays a bonus $\Delta \mathrm{b} \equiv \mathrm{b}_{\mathrm{H}}-\mathrm{b}_{\mathrm{L}}$ if $\mathrm{Q}=\mathrm{Q}_{\mathrm{H}}$ and a bonus $\Delta \beta \equiv \beta_{\mathrm{H}}-\beta_{\mathrm{L}}$ if $\mathrm{P}=\mathrm{P}_{\mathrm{H}}$, with no further bonus payable if both $\mathrm{Q}$ and $\mathrm{P}$ achieve their high values. ${ }^{14}$ Under this assumption about bonus payments in relational contracts, the upstream party chooses $a_{1}$ and $a_{2}$ to maximize $\left(s+b_{L}+\beta_{L}\right)+q(a) \Delta b+$ $\mathrm{p}(\mathbf{a}) \Delta \beta-\mathrm{c}(\mathbf{a})$, so

$$
\begin{aligned}
& \mathrm{a}_{1}{ }^{\mathrm{R}}=\mathrm{q}_{1} \Delta \mathrm{b}+\mathrm{p}_{1} \Delta \beta \quad \text { and } \\
& \mathrm{a}_{2}{ }^{\mathrm{R}}=\mathrm{q}_{2} \Delta \mathrm{b}+\mathrm{p}_{2} \Delta \beta,
\end{aligned}
$$

where "R" connotes relational contract (and will be replaced by either "RO" for relational outsourcing or "RE" for relational employment below). As we show in Appendix 1, the necessary and sufficient conditions for self-enforcing relational-employment contracts (10) and relational-outsourcing contracts (16) then take the simpler forms (10') and (16'):

$$
\begin{gathered}
|\Delta \mathrm{b}|+|\Delta \beta| \leq \frac{1}{\mathrm{r}}\left(\mathrm{S}^{\mathrm{RE}}-\max \left[\mathrm{S}^{\mathrm{SO}}, \mathrm{S}^{\mathrm{SE}}\right]\right), \\
\left|\Delta \mathrm{b}-\frac{1}{2} \Delta \mathrm{Q}\right|+\left|\Delta \beta-\frac{1}{2} \Delta \mathrm{P}\right| \leq \frac{1}{\mathrm{r}}\left(\mathrm{S}^{\mathrm{RO}}-\max \left[\mathrm{S}^{\mathrm{SO}}, \mathrm{S}^{\mathrm{SE}}\right]\right) .
\end{gathered}
$$

Given (18), the first-best can be achieved under a relational contract if and only if $\Delta b=\Delta Q$ and $\Delta \beta=0$, so (10') implies that the first-best can be achieved under relational employment if and only if

$$
\Delta \mathrm{Q} \leq \frac{1}{\mathrm{r}}\left(\mathrm{S}^{\mathrm{FB}}-\max \left[\mathrm{S}^{\mathrm{SO}}, \mathrm{S}^{\mathrm{SE}}\right]\right)
$$

14. In combination with our assumption that $\mathrm{q}_{1} \mathrm{p}_{2} \neq \mathrm{q}_{2} \mathrm{p}_{1}$, these restricted bonus payments imply a one-toone correspondence between action vectors and bonus payments, which greatly simplifies the computations underlying Figure II and some of the results below. 
where $S^{F B}$ is the first-best total surplus, $Q_{L}+\frac{1}{2} q^{2} \Delta Q^{2}$. Similarly, (16') implies that the firstbest can be achieved under relational outsourcing if and only if

$$
\frac{1}{2}(\Delta \mathrm{Q}+\Delta \mathrm{P}) \leq \frac{1}{\mathrm{r}}\left(\mathrm{S}^{\mathrm{FB}}-\max \left[\mathrm{S}^{\mathrm{SO}}, \mathrm{S}^{\mathrm{SE}}\right]\right) .
$$

From (19) and (20) we see that at sufficiently small discount rates the first-best is achievable under either relational employment or outsourcing. But if $\Delta \mathrm{P}>\Delta \mathrm{Q}$ then there exist intermediate discount rates where the first-best is achievable under relational employment but not under relational outsourcing, and if $\Delta \mathrm{P}<\Delta \mathrm{Q}$ then there are discount rates where the first-best is achievable under relational outsourcing but not under relational employment. As noted above, these observations generate a first illustration of Result 3: the optimal integration decision can depend on the discount rate.

\section{B. Additional Results}

In this sub-section we state and interpret formal versions of our five additional results. (Proofs are in Appendix 2.)

Before proving these results, we build intuition via the following "unproductive multitasking" example: the agent can take one action that affects $\mathrm{Q}$ and another that affects $\mathrm{P}$ (i.e., $\mathrm{q}_{2}=\mathrm{p}_{1}=0$, so the probabilities of realizing $\mathrm{Q}=\mathrm{Q}_{\mathrm{H}}$ and $\mathrm{P}=\mathrm{P}_{\mathrm{H}}$ can be written $\mathrm{q}(\mathbf{a})=\mathrm{qa}_{1}$ and $\mathrm{p}(\mathbf{a})=\mathrm{pa}_{2}$, respectively). Figure II plots the efficient organizational form for this unproductive-multitasking example, as a function of $\mathrm{r}$ and $\Delta \mathrm{P}$. The figure contains five regions indicating the governance structure that produces the highest total surplus in each region of parameter space. When discount rates are high, relational contracts are not feasible, so either spot outsourcing or spot employment is efficient. Spot outsourcing yields total surplus $\mathrm{S}^{\mathrm{SO}}=$ $\mathrm{Q}_{\mathrm{L}}+\frac{3}{8} \mathrm{q}^{2} \Delta \mathrm{Q}^{2}-\frac{1}{8} \mathrm{p}^{2} \Delta \mathrm{P}^{2}$ while spot employment yields $\mathrm{S}^{\mathrm{SE}}=\mathrm{Q}_{\mathrm{L}}$, so spot outsourcing dominates spot employment if and only if $\mathrm{p} \Delta \mathrm{P}<\sqrt{3} \mathrm{q} \Delta \mathrm{Q}$, as can be seen at the top of the figure. At intermediate discount rates, total surplus is maximized by relational outsourcing or relational employment (at either second- or first-best surplus, depending on the discount rate). Finally, when discount rates are sufficiently low, the first-best can be achieved through both relational outsourcing and relational employment. Figure II is thus a formal version of the CoaseWilliamson horse race between markets and firms, but we will also use it to illustrate several of the following results.

Result 1: Vertical integration is an efficient response to widely varying supply prices. Formally, given $\mathrm{q}_{1}, \mathrm{q}_{2}, \mathrm{p}_{1}, \mathrm{p}_{2}, \Delta \mathrm{Q}$, and $\mathrm{r}$ there exists $\Delta \mathrm{P}^{*}$ such that if $\Delta \mathrm{P}>\Delta \mathrm{P}^{*}$ then the downstream party owns the asset in the efficient governance structure. 
Under relational outsourcing, the upstream party could consign the good to its alternative use, so current market conditions (that is, realizations of $\mathrm{P}_{\mathrm{L}}$ or $\mathrm{P}_{\mathrm{H}}$ ) play an important role in determining whether the parties will honor the relational-outsourcing contract. In contrast, under relational employment, current market conditions do not affect the reneging decision because the downstream owner can simply take the good, without any restitution to the upstream party whatsoever. This distinction is clear from the reneging constraints: $\Delta \mathrm{P}$ appears in the constraint for relational outsourcing, $\left(16^{\prime}\right)$, but not in the constraint for relational employment, $\left(10^{\prime}\right)$. As a result, increases in $\Delta \mathrm{P}$ cause relational outsourcing to become infeasible (follow the arrow labeled R1 in Figure II).

This difference between relational outsourcing and relational employment offers an explanation for Carlton's [1979: 189] observation that companies vertically integrate to reduce uncertainty of supply.

"It has always been somewhat of a mystery why businessmen, as well as researchers, so often conclude that the significant force explaining . . . vertical integration ... has been the desire to obtain a more certain supply of inputs. ... Why are markets not doing their jobs of allocating resources, and why should uncertainty create incentives for vertical integration?"

While Carlton proposes an answer to this question that depends on price rigidities that keep supply from equaling demand in some circumstances, our model suggests an alternative answer that does not depend on such non-market clearing mechanisms. In our model, anticipated price fluctuations make vertical integration efficient not because of ex ante uncertainty associated with a volatile market price, but rather because of the ex post temptation to renege on a relational contract. ${ }^{15}$ Specifically, the upstream producer faces a large temptation to renege when the price is high, and the downstream consumer faces a large temptation when the price is low. These temptations make it difficult to sustain a relational-outsourcing contract, but after vertical integration the market price $\mathrm{P}$ no longer serves as a temptation to either party. ${ }^{16}$

Result 2: High-powered incentives create bigger reneging temptations under integration than under non-integration, with the consequence that performance payments in relational

15. In our model, a high $\Delta \mathrm{P}$ represents a large variability in the value of the good in its next-best use. We interpret a high $\Delta \mathrm{P}$ as meaning that the market price of the good is highly variable.

16. See Goldberg and Erickson [1987], Klein [1996], and Klein and Murphy [1997] for similar arguments applied to particular industries. Arrow [1975] also suggests that variation in supply prices may explain vertical integration, but his result is based on acquiring information to improve price forecasting rather than on the temptation to renege on relational contracts. 
incentive contracts will be smaller in firms than in (otherwise equivalent) markets. Formally, given $\mathrm{q}_{1}, \mathrm{q}_{2}, \mathrm{p}_{1}, \mathrm{p}_{2}, \Delta \mathrm{Q}, \Delta \mathrm{P}$, and $\mathrm{r}$, if the most efficient relationalemployment contract yields $\mathrm{a}_{1}{ }^{\mathrm{RE}}<\mathrm{a}_{1}{ }^{\mathrm{FB}}$ and $\mathrm{a}_{2}{ }^{\mathrm{RE}}<\mathrm{a}_{2}{ }^{\mathrm{FB}}$ then either the most efficient relational-outsourcing contract yields $\mathrm{a}_{1}{ }^{\mathrm{RO}}>\mathrm{a}_{1}{ }^{\mathrm{RE}}$ and $\mathrm{a}_{2}{ }^{\mathrm{RO}}>\mathrm{a}_{2}{ }^{\mathrm{RE}}$ or no relationaloutsourcing contract exists.

As explained earlier, under relational outsourcing the temptation for the downstream party to renege is not the full amount of a promised payment but only the difference between the promised payment and the payment that would be determined by bargaining. More formally, the upstream party's actions are determined by $\Delta b$ and $\Delta \beta$ (these are the "bonuses" paid for achieving high realizations of $\mathrm{Q}$ and $\mathrm{P}$, respectively), so holding $\Delta \mathrm{b}$ and $\Delta \beta$ fixed, the total surplus from relational contracting does not depend on who owns the asset. But the temptation to renege, shown on the left-hand sides of $\left(10^{\prime}\right)$ and (16'), does depend on asset ownership. In particular, if strong incentives are desirable (i.e., $\Delta \mathrm{b}>\frac{1}{2} \Delta \mathrm{Q}$ and $\Delta \beta>\frac{1}{2} \Delta \mathrm{P}$ ) then the total reneging temptation is smaller under relational outsourcing than under relational employment (namely, $\left|\Delta \mathrm{b}-\frac{1}{2} \Delta \mathrm{Q}\right|+\left|\Delta \beta-\frac{1}{2} \Delta \mathrm{P}\right|$ rather than $\left.|\Delta \mathrm{b}|+|\Delta \beta|\right)$. Thus, when strong incentives are desirable, relational employment is an inefficient governance mechanism compared to relational outsourcing.

Result 2 corresponds to a thought experiment: fix the environment, measure the incentive payments in the optimal organizational form, and consider what incentive payments would emerge if the organizational form were changed. But an empirical test along these lines would require that non-optimal organizational forms exist in the given environment. Fortunately, a related result also holds: choose a dataset with a narrow range of environments in which both relational outsourcing and employment exist. In this range of environments, outsourcing contracts will have larger incentive payments than employment contracts will have.

As an example of the latter thought experiment, consider the boundary between relational outsourcing and relational employment denoted by R2 in Figure II. Along this boundary (which occurs when $\Delta \mathrm{Q}<\Delta \mathrm{P}<\sqrt{2} \mathrm{q} \Delta \mathrm{Q} / \mathrm{p}$ ), the surpluses generated under the two relational contracts are identical, but the contracts themselves are different: the optimal contract under relational employment is $\Delta \mathrm{b}^{\mathrm{RE}}>0$ and $\Delta \beta^{\mathrm{RE}}=0$, while the optimal contract under relational outsourcing is $\Delta \mathrm{b}^{\mathrm{RO}}>\Delta \mathrm{b}^{\mathrm{RE}}$ and $\Delta \beta^{\mathrm{RO}}>\Delta \beta^{\mathrm{RE}}>0$. Therefore, along this boundary, (14) implies that the upstream party will work harder on both tasks under relational outsourcing than relational employment: $a_{1}{ }^{R O}>a_{1}{ }^{R E}$ and $a_{2}{ }^{R O}>a_{2}{ }^{R E}=0$. Intuitively, in this unproductivemultitasking example, setting $\Delta \beta>0$ to encourage the unproductive action $\mathrm{a}_{2}$ reduces total surplus on the right side of (16'), but also reduces the reneging temptation on the left side of 
(16'). At $\mathrm{a}_{2}=0$, the former is second-order but the latter is first-order, so $\Delta \mathrm{b}$ can be increased to increase the productive action $\mathrm{a}_{1}$.

Result 3: The optimal integration decision can depend on the discount rate. Formally, there exist parameters $\mathrm{q}_{1}, \mathrm{q}_{2}, \mathrm{p}_{1}, \mathrm{p}_{2}, \Delta \mathrm{Q}, \Delta \mathrm{P}$ such that at intermediate discount rates the first-best can be achieved by relational employment but not by relational outsourcing, but at high discount rates no relational contract is feasible and spot outsourcing yields higher total surplus than does spot employment.

Given (18), first-best relational contracts require $\Delta \mathrm{b}=\Delta \mathrm{Q}$ and $\Delta \beta=0$. Conditions (19) and (20) show that the first-best is always achievable under either ownership structure at sufficiently low discount rates, and also that the first-best contract generates higher (or lower) reneging temptation under relational outsourcing than under relational employment when $\Delta \mathrm{P}>\Delta \mathrm{Q}$ or $(\Delta \mathrm{P}<\Delta \mathrm{Q})$.

The arrow labeled R3 in Figure II illustrates how the discount rate can affect the optimal organizational form. At sufficiently low discount rates, both relational outsourcing and relational employment can achieve the first-best. But because $\Delta \mathrm{P}>\Delta \mathrm{Q}$ in this region of the figure, as the discount rate increases the first-best becomes infeasible under relational outsourcing but is still feasible under relational employment. At still higher discount rates, relational employment still dominates relational outsourcing but neither can achieve the firstbest. Finally, at sufficiently high discount rates, the optimal organizational form switches to outsourcing—initially to second-best relational outsourcing and then to spot outsourcing.

Result 4: Holding all marginal incentives constant, the optimal integration decision can depend on the payoff levels. Formally, holding $\mathrm{q}_{i} \Delta \mathrm{Q}+\mathrm{p}_{\mathrm{i}} \Delta \mathrm{P}$ constant for $\mathrm{i}=1,2$ fixes the choice between spot employment or spot outsourcing, but changing $\Delta \mathrm{P}$ or $\Delta \mathrm{Q}$ (with corresponding changes in $\mathrm{p}_{\mathrm{i}}$ or $\mathrm{q}_{\mathrm{i}}$ to keep $\mathrm{q}_{\mathrm{i}} \Delta \mathrm{Q}+\mathrm{p}_{\mathrm{i}} \Delta \mathrm{P}$ constant) affects the reneging temptations and hence the choice between relational employment and relational outsourcing.

Changes in $\Delta \mathrm{P}$ or $\Delta \mathrm{Q}$ have two effects in our model. First, these changes affect the reneging temptations in (10') and (16') because the bargaining position of the upstream party after reneging depends on who owns the asset. Second, (17) shows that changes in $\Delta \mathrm{P}$ or $\Delta \mathrm{Q}$ affect the optimal upstream action choices under spot outsourcing and so affect the comparison between spot outsourcing and spot employment. In developing Result 4, we neutralize the 
second effect by holding marginal incentives constant; that is, we allow $\Delta \mathrm{P}$ or $\Delta \mathrm{Q}$ to vary while holding constant $\mathrm{q}_{1} \Delta \mathrm{Q}+\mathrm{p}_{1} \Delta \mathrm{P}$ and $\mathrm{q}_{2} \Delta \mathrm{Q}+\mathrm{p}_{2} \Delta \mathrm{P}$. As an example, think of doubling the potential increase in alternative-use value, $\Delta \mathrm{P} \equiv \mathrm{P}_{\mathrm{H}}-\mathrm{P}_{\mathrm{L}}$, while halving the probability of obtaining $\mathrm{P}_{\mathrm{H}}$ for any vector of actions (that is, reducing $\mathrm{p}_{1}$ and $\mathrm{p}_{2}$ by half). This change has no affect on spotmarket outcomes but does affect the reneging temptations and therefore the optimal asset ownership structure.

Result 4 is perhaps our most striking point of departure from static theories of asset ownership in the tradition of Grossman-Hart, in which everything is determined by marginal incentives and payoff levels are irrelevant. ${ }^{17}$ Intuitively, the level of total surplus is critical in our repeated-game model, because this surplus must be sufficient to deter reneging. Marginal incentives also matter in our theory, but for roughly the same reasons as in the static models.

Result 5: A mediocre spot market may prevent the existence of any firm, including a firm that would be more efficient than the spot market. Formally, suppose that $\mathrm{q}_{1}, \mathrm{q}_{2}, \mathrm{p}_{1}, \mathrm{p}_{2}$, $\Delta \mathrm{Q}$, and $\Delta \mathrm{P}$ imply that spot outsourcing dominates spot employment $\left(\mathrm{S}^{\mathrm{SO}}>\mathrm{S}^{\mathrm{SE}}\right)$. Then there exists $r^{*}$ such that if $r>r^{*}$ then no values of $\Delta b$ and $\Delta \beta$ satisfy the reneging constraint $\left(10^{\prime}\right){ }^{18}$

Result 5 extends the corollary in Section III: we have already shown that a firm cannot mimic the spot-market outcome after it brings a transaction inside the firm; we now show that the firm may also be unable to improve upon the spot-market outcome, because the availability of spot-market outcome as a fallback after reneging may render infeasible any desirable relational-employment contract.

To provide some intuition for Result 5, we can extend the proof of the corollary by a continuity argument, as follows. Suppose that spot outsourcing dominates spot employment, $\mathrm{S}^{\mathrm{SO}}>\mathrm{S}^{\mathrm{SE}}$, and recall that a relational contract paying bonuses $\Delta \mathrm{b}=\frac{1}{2} \Delta \mathrm{Q}$ and $\Delta \beta=\frac{1}{2} \Delta \mathrm{P}$ will reproduce the spot-market outcome, $\mathrm{S}^{\mathrm{RE}}(\Delta \mathrm{b}, \Delta \beta)=\mathrm{S}^{\mathrm{SO}}$. Now consider bonuses $\Delta \mathrm{b}^{\prime}$ and $\Delta \beta^{\prime}$ that are near $\Delta \mathrm{b}=\frac{1}{2} \Delta \mathrm{Q}$ and $\Delta \beta=\frac{1}{2} \Delta \mathrm{P}$ but generate slightly higher surplus, $\mathrm{S}^{\mathrm{RE}}\left(\Delta \mathrm{b}^{\prime}, \Delta \beta^{\prime}\right)>\mathrm{S}^{\mathrm{SO}}$. Then the left side of (10') is near $\frac{1}{2} \Delta \mathrm{Q}+\frac{1}{2} \Delta \mathrm{P}$ but the right side is only slightly above zero, so (10') fails. Thus, small improvements on the spot-market outcome will not be feasible (where

17. We thank a referee for noting that not all static theories of asset ownership share the feature that payoff levels are irrelevant. For example, DeMeza and Lockwood [1998] change the bargaining game in the GrossmanHart model and reverse this result.

18. In Appendix 2 we not only prove this result but state and prove the analogous result for employment: mediocre spot employment can prevent the existence of any outsourcing. 
the definition of "small" depends on the discount rate). It remains to show that large improvements on the spot-market outcome are not feasible, which we do in Appendix 2. ${ }^{19}$

\section{Discussion}

This paper integrates two prominent strands of the literature on the theory of the firm: asset ownership and relational contracting. Because others have explored asset ownership (e.g., Grossman and Hart), relational contracts within firms (e.g., Bull), and relational contracts between firms (e.g., Klein and Leffler), we focus on comparing relational contracts within firms to those between. Our main proposition is that asset ownership affects the parties' temptations to renege on a relational contract, so the integration decision is determined in part by the different relational contracts facilitated by asset ownership. As a corollary, we show that firms cannot replicate spot-market outcomes, because the reneging temptation is too great once the transaction is brought inside the firm. We also derive five related results: (1) vertical integration is an efficient response to widely varying supply prices; (2) high-powered incentives create bigger reneging temptations under integration than under non-integration; (3) the discount rate may affect optimal asset ownership; (4) the level of payoffs, not just the marginal incentives, can affect the integration decision; and (5) firms cannot improve on the spot-market outcome if that outcome offers too tempting a fallback after reneging.

In this section we consider four additional issues: the sociological literature on the formal and informal aspects of organizational design; how our approach might be applied to understanding other organizational forms; the implications of our analysis for internal organizational processes; and a role for managers in the economic theory of the firm.

\section{A. Formal vs. Informal Aspects of Organizational Structure}

Organizational sociologists have long emphasized the distinction between formal and informal aspects of organizational structure. Formal aspects include official job descriptions and reporting relationships, as well as formal contracts (i.e., contracts that can be enforced by a court). Informal aspects include norms and mutual understandings, as well as network

19. Baker, Gibbons, and Murphy [1994] establish a similar result involving compensation contracts: relational contracts are feasible only if formal contracts are sufficiently inferior. MacLeod and Malcolmson [1989] anticipated part of this result, by showing that surplus is necessary for a relational contract to exist. Relative to their result, there are two innovations in our two papers. First, we endogenize the performance of the spot-governance alternative to a relational contract. That is, rather than taking the payoffs from spot governance to be exogenous, we derive these payoffs in the same economic environment in which we analyze relational contracts. Second, we show that in our models surplus is necessary but not sufficient. 
structures among individuals (i.e., who you know in the organization besides the people to whom you have formal reporting ties). Roughly speaking, the formal structure is the organization chart, whereas the informal structure is the way things really work. As Granovetter [1985: 502] notes:

The distinction between the 'formal' and the 'informal' organization of the firm is one of the oldest in the literature, and it hardly needs repeating that observers who assume firms to be structured in fact by the official organization chart are sociological babes in the woods.

Blau and Scott [1962: 6] go further, asserting that formal and informal aspects not only co-exist but interact:

It is impossible to understand the nature of a formal organization without investigating the networks of informal relations and the unofficial norms as well as the formal hierarchy of authority and the official body of rules, since the formally instituted and the informal emerging patterns are inextricably intertwined.

Asset ownership is a formal aspect of organizational structure; relational contracts are informal. By integrating the two in a single economic model, we are catching up with the sociologists. Yet there is value added by our economic approach: because ownership and relational contracts interact (rather than just co-exist), we can choose the former to facilitate the latter, thereby optimizing overall organizational performance. As we describe in the next two sub-sections, there are many potential applications of this idea. ${ }^{20}$

\section{B. Other Organizational Forms}

In this paper we analyze the four organizational forms shown in Figure I, devoting most of our attention to the two on the bottom row: relational employment and relational outsourcing. While these four organizational forms expand and clarify the traditional distinction between markets and firms, they only hint at the variety of forms now much discussed in the business and organizational literatures, including joint ventures, strategic alliances, networks, business groups, clans, and virtual organizations. ${ }^{21}$ Unlike the business and organizational literatures, however, the economics literature has not had much to say about these non-standard organizational forms. Furthermore, where these forms have received theoretical attention from

20. The broader statement of this idea is that one should choose all formal aspects (not just ownership) by taking into account their consequences for all informal aspects (not just relational contracts). For other applications of this idea, see Williamson [1985, Chapters 7-8] on hostages, Kahn and Huberman [1988] on upor-out rules, and Bernheim and Whinston [1998] on strategic ambiguity.

21. See, for instance, Chesborough and Teece [1996], Dyer [1996], Gerlach [1991], Granovetter [1995], Gulati and Singh [1998], Kogut [1989], Miles and Snow [1992], Pisano [1989], and Powell [1990]. 
economists, the focus has typically been on asset ownership and other formal aspects of organizational structure, such as in Rey and Tirole [1999].

We suspect that informal aspects, especially relational contracts, are important to the success of these non-traditional organizational forms. We also suspect that the formal and informal aspects not only co-exist but also interact, creating another opportunity to choose the former to facilitate the latter. Although the model in this paper has only two stages of production with one party at each stage, richer models could add both parties and stages. For example, one could begin to model a joint venture as two parties at one stage who create an asset at the other stage which they control by both formal and informal means. Similarly, one could begin to model a business group as several parties at several stages of production, with both cross-ownership and relational contracts linking the parties, possibly through a central party. We expect that formal structures such as fifty-fifty ownership in joint ventures or minority stock holdings in business groups will be better understood using models that study the interplay between these formal structures and the informal relational contracts between the parties. See Bragelien [2000] for a promising start along these lines.

\section{Internal Organizational Processes}

Of course, the interplay between formal and informal organizational structures is not limited to relationships between firms; there are many applications of this idea within firms. We argue that one particular form of informal structure-subjective judgments whose force depends on parties' reputations-plays a crucial role in organizational processes such as transfer pricing, capital budgeting, compensation, and corporate governance. These organizational processes are not simple exercises in formal contracting, as they often appear in the economics literature, but rather have important informal aspects. We suspect that these informal aspects can be hampered or facilitated by formal organizational structures, such as whether the firm is organized by function versus division, whether its jobs are defined for individuals or teams, and so on. As above, we envision a class of models in which formal organizational structures interact with informal relational contracts.

To conserve space, we discuss only transfer pricing and corporate governance. ${ }^{22}$ Early research on transfer pricing (e.g., Hirshleifer [1956], Gould [1964]) treated this problem as one of trying to recreate the market inside the firm, so that decentralized agents will face incentives that produce efficient resource allocation. But Eccles [1985] conducted an extensive field study

22. See Bower [1970] on the role of subjectivity, judgment, and reputation in the determination of divisional capital allocations, and Lawler [1971] on how compensation rarely relies exclusively on objective measures of performance, instead relying heavily on managerial subjectivity and judgment. 
of transfer pricing practices and found that transfer prices are rarely used to allocate resources. Instead, the rights to allocate resources are held centrally, with the transfer-pricing scheme serving as part of the performance measurement and incentive system for the divisions. Our model is consistent with Eccles's findings. Under relational employment, the transfer payment does not serve to allocate resources or transfer ownership in the good produced, because the good is already owned by the downstream party. Rather, the purpose of the transfer payment is to provide incentives for the upstream party to take actions that make the good more valuable downstream.

As another example of subjectivity in organizational processes, consider corporate governance. One of the original motivations for agency theory was to model the relationship between managers and investors. Yet the relationship between managers and shareholders is seldom mediated entirely, or even largely, by formal contracts. Executive compensation contracts in corporations almost always give significant discretion to the board of directors in determining both the size and timing of payouts (see Kole [1997]). We argue that the role of the board is to design and implement a relational contract between management and the shareholders. Using a variety of objective and subjective measures of performance, the board attempts to disentangle the effects of management's actions from those of luck [Lorsch and McIver, 1994] and to eliminate distortions induced by accounting-based measures of performance [Dechow, Huson, and Sloan, 1994]. Thus, corporate governance is again an interaction between formal and informal systems.

\section{Conclusion: Management and the Nature of the Firm}

We find it curious that most of the literature on the theory of the firm makes little reference to (non-owner) managers. By emphasizing the importance of relational contracts, our model highlights a role for managers: the development and maintenance of relational contracts, both within and between firms. In our model, this role involves designing the relational contract (that is, determining what the observable but non-contractible Q's and P's should be, as well as determining the optimal $b_{\mathrm{ij}}{ }^{\prime} \mathrm{s}$ ), communicating this to employees, assessing outcomes (that is, observing the Q's and P's), and deciding whether to honor the relational contract (that is, properly evaluating the reneging constraints). In our model these tasks are trivial; in reality each requires judgment and knowledge of the specifics of complex situations. Furthermore, hard as these tasks are in practice, much evidence suggests that changing a relational contract is harder still: managers must end one relational contract but preserve enough credibility to begin another, and the new contract they seek to begin often looks suspiciously like reneging on the old one they seek to end! 
We are not arguing that such management of relational contracts occurs only in firms. To the contrary, we have emphasized that management is crucial in ongoing supply relationships. Nor are we arguing that firms cannot occur without management. That is, we can imagine firms that fit the Grossman-Hart model, in which all non-contractible rights of control are held by a single individual ("spot employment" in Figure I). But if these rights become too numerous and complex to be held by a single individual, the firm must have some mechanism to coordinate their exercise, and because these rights are not contractible, their exercise cannot be controlled by formal contracts. Rather, the exercise of non-contractible rights must be coordinated by relational contracts. In short, the firm must have managers ("relational employment" in Figure I). We conclude that understanding the role of managers, who design and implement the relational contracts that underpin informal organizational processes, is essential to understanding firms. 


\section{APPENDicies}

\section{APPENDIX 1. NeCessary and Sufficient Conditions for SElf-Enforcing Relational Contracts when Payments are $b_{\mathrm{ij}}=b_{\mathrm{i}}+\beta_{\mathrm{j}}$}

\section{Relational Employment}

Equation (10) provides the necessary and sufficient condition for the relational-employment contract $\left(s,\left\{b_{i j}\right\}\right)$ to be self-enforcing:

When $b_{i j}=b_{i}+\beta_{j}$, there are four cases to consider.

$$
\max \left(b_{i j}\right)-\min \left(b_{i j}\right) \leq \frac{1}{r}\left(S^{R E}-\max \left[S^{S O}, S^{S E}\right]\right) .
$$

1. $b_{\mathrm{H}}>\mathrm{b}_{\mathrm{L}}, \beta_{\mathrm{H}}>\beta_{\mathrm{L}}$. Then $\max \left(\mathrm{b}_{\mathrm{ij}}\right)=\mathrm{b}_{\mathrm{HH}}, \min \left(\mathrm{b}_{\mathrm{ij}}\right)=\mathrm{b}_{\mathrm{LL}}$, and the reneging temptation is $\Delta \mathrm{b}+$ $\Delta \beta$, where $\Delta \mathrm{b} \equiv \mathrm{b}_{\mathrm{H}}-\mathrm{b}_{\mathrm{L}}>0$ and $\Delta \beta \equiv \beta_{\mathrm{H}}-\beta_{\mathrm{L}}>0$.

2. $b_{\mathrm{H}}>\mathrm{b}_{\mathrm{L}}, \beta_{\mathrm{H}}<\beta_{\mathrm{L}}$. Then $\max \left(\mathrm{b}_{\mathrm{ij}}\right)=\mathrm{b}_{\mathrm{HL}}, \min \left(\mathrm{b}_{\mathrm{ij}}\right)=\mathrm{b}_{\mathrm{LH}}$, and the reneging temptation is $\Delta \mathrm{b}-$ $\Delta \beta$, where $\Delta \mathrm{b}>0$ and $\Delta \beta<0$.

3. $b_{\mathrm{H}}<b_{\mathrm{L}}, \beta_{\mathrm{H}}>\beta_{\mathrm{L}}$. Then $\max \left(\mathrm{b}_{\mathrm{ij}}\right)=\mathrm{b}_{\mathrm{LH}}, \min \left(\mathrm{b}_{\mathrm{ij}}\right)=\mathrm{b}_{\mathrm{HL}}$, and the reneging temptation is $-\Delta \mathrm{b}+$ $\Delta \beta$, where $\Delta \mathrm{b}<0$ and $\Delta \beta>0$.

4. $\mathrm{b}_{\mathrm{H}}<\mathrm{b}_{\mathrm{L}}, \beta_{\mathrm{H}}<\beta_{\mathrm{L}}$. Then $\max \left(\mathrm{b}_{\mathrm{ij}}\right)=\mathrm{b}_{\mathrm{LL}}, \min \left(\mathrm{b}_{\mathrm{ij}}\right)=\mathrm{b}_{\mathrm{LL}}$, and the reneging temptation is $-\Delta \mathrm{b}-$ $\Delta \beta$, where $\Delta b<0$ and $\Delta \beta<0$.

These four reneging temptations can be summarized as $|\Delta \mathrm{b}|+|\Delta \beta|$, yielding

$$
|\Delta \mathrm{b}|+|\Delta \beta| \leq \frac{1}{\mathrm{r}}\left(\mathrm{S}^{\mathrm{RE}}-\max \left[\mathrm{S}^{\mathrm{SO}}, \mathrm{S}^{\mathrm{SE}}\right]\right)
$$

\section{Relational Outsourcing}

Equation (16) provides the necessary and sufficient condition for the relational-outsourcing contract $\left(s,\left\{b_{i j}\right\}\right)$ to be self-enforcing:

$$
\max \left(b_{i j}-\frac{1}{2}\left(Q_{i}+P_{j}\right)\right)-\min \left(b_{i j}-\frac{1}{2}\left(Q_{i}+P_{j}\right)\right) \leq \frac{1}{r}\left(S^{R O}-\max \left[S^{S O}, S^{S E}\right]\right) .
$$

Define $\mathrm{Z} \equiv \mathrm{b}_{\mathrm{L}}+\beta_{\mathrm{L}}-\frac{1}{2}\left(\mathrm{Q}_{\mathrm{L}}+\mathrm{P}_{\mathrm{L}}\right)$, and note that

$$
\begin{aligned}
& \mathrm{b}_{\mathrm{HH}}-\frac{1}{2}\left(\mathrm{Q}_{\mathrm{H}}+\mathrm{P}_{\mathrm{H}}\right)=\left(\Delta \mathrm{b}-\frac{1}{2} \Delta \mathrm{Q}\right)+\left(\Delta \beta-\frac{1}{2} \Delta \mathrm{P}\right)+\mathrm{Z} \\
& \mathrm{b}_{\mathrm{HL}}-\frac{1}{2}\left(\mathrm{Q}_{\mathrm{H}}+\mathrm{P}_{\mathrm{L}}\right)=\left(\Delta \mathrm{b}-\frac{1}{2} \Delta \mathrm{Q}\right)+\mathrm{Z} \\
& \mathrm{b}_{\mathrm{LH}}-\frac{1}{2}\left(\mathrm{Q}_{\mathrm{L}}+\mathrm{P}_{\mathrm{H}}\right)=\left(\Delta \beta-\frac{1}{2} \Delta \mathrm{P}\right)+\mathrm{Z} \\
& \mathrm{b}_{\mathrm{LL}}-\frac{1}{2}\left(\mathrm{Q}_{\mathrm{L}}+\mathrm{P}_{\mathrm{L}}\right)=\mathrm{Z}
\end{aligned}
$$

Again, there are four cases to consider.

1. $\Delta \mathrm{b}>\frac{1}{2} \Delta \mathrm{Q}, \Delta \beta>\frac{1}{2} \Delta \mathrm{P}$. Then $\max (\bullet)=\mathrm{HH}, \min (\bullet)=\mathrm{LL}$, and the reneging temptation is 


$$
\left(\Delta \mathrm{b}-\frac{1}{2} \Delta \mathrm{Q}\right)+\left(\Delta \beta-\frac{1}{2} \Delta \mathrm{P}\right)
$$

2. $\Delta \mathrm{b}>\frac{1}{2} \Delta \mathrm{Q}, \Delta \beta<\frac{1}{2} \Delta \mathrm{P}$. Then $\max (\bullet)=\mathrm{HL}, \min (\bullet)=\mathrm{LH}$, and the reneging temptation is $\left(\Delta \mathrm{b}-\frac{1}{2} \Delta \mathrm{Q}\right)-\left(\Delta \beta-\frac{1}{2} \Delta \mathrm{P}\right)$.

3. $\Delta \mathrm{b}<\frac{1}{2} \Delta \mathrm{Q}, \Delta \beta>\frac{1}{2} \Delta \mathrm{P}$. Then $\max (\bullet)=\mathrm{LH}, \min (\bullet)=\mathrm{HL}$, and the reneging temptation is $-\left(\Delta \mathrm{b}-\frac{1}{2} \Delta \mathrm{Q}\right)+\left(\Delta \beta-\frac{1}{2} \Delta \mathrm{P}\right)$.

4. $\Delta \mathrm{b}<\frac{1}{2} \Delta \mathrm{Q}, \Delta \beta<\frac{1}{2} \Delta \mathrm{P}$. Then $\max (\bullet)=\mathrm{LL}, \min (\bullet)=\mathrm{HH}$, and the reneging temptation is $-\left(\Delta \mathrm{b}-\frac{1}{2} \Delta \mathrm{Q}\right)-\left(\Delta \beta-\frac{1}{2} \Delta \mathrm{P}\right)$.

These four reneging temptations can be summarized as $\left|\Delta \mathrm{b}-\frac{1}{2} \Delta \mathrm{Q}\right|+\left|\Delta \beta-\frac{1}{2} \Delta \mathrm{P}\right|$, yielding

$$
\left|\Delta \mathrm{b}-\frac{1}{2} \Delta \mathrm{Q}\right|+\left|\Delta \beta-\frac{1}{2} \Delta \mathrm{P}\right| \leq \frac{1}{\mathrm{r}}\left(\mathrm{S}^{\mathrm{RO}}-\max \left[\mathrm{S}^{\mathrm{SO}}, \mathrm{S}^{\mathrm{SE}}\right]\right)
$$




\section{APPENDiX 2. Proofs of Results 1 through 5.}

Result 1: Vertical integration is an efficient response to widely varying supply prices. Formally, given $\mathrm{q}_{1}, \mathrm{q}_{2}, \mathrm{p}_{1}, \mathrm{p}_{2}, \Delta \mathrm{Q}$, and $\mathrm{r}$ there exists $\Delta \mathrm{P}^{*}$ such that if $\Delta \mathrm{P}>\Delta \mathrm{P}^{*}$ then the downstream party owns the asset in the efficient governance structure.

Proof: $\quad$ Given Lemmas 1 and 3 below, Result 1 follows by setting $\Delta \mathrm{P}^{*}=\max \left\{\Delta \mathrm{P}^{\prime}, \Delta \mathrm{P}^{\prime \prime}\right\}$ : because $\Delta \mathrm{P}>\Delta \mathrm{P}^{\prime}$, spot outsourcing is not efficient; because $\Delta \mathrm{P}>\Delta \mathrm{P}^{\prime \prime}$, relational outsourcing is not feasible.

Lemma 1: For sufficiently large $\Delta \mathrm{P}$, spot employment dominates spot outsourcing. That is, given $\mathrm{q}_{1}, \mathrm{q}_{2}, \mathrm{p}_{1}, \mathrm{p}_{2}$, and $\Delta \mathrm{Q}$ there exists $\Delta \mathrm{P}^{\prime}$ such that if $\Delta \mathrm{P}>\Delta \mathrm{P}^{\prime}$ then $\mathrm{S}^{\mathrm{SE}}>\mathrm{S}^{\mathrm{SO}}$.

Proof: $\quad 2\left(\mathrm{~S}^{\mathrm{SO}}-\mathrm{S}^{\mathrm{SE}}\right)=(3 / 4)\left(\mathrm{q}_{1}{ }^{2}+\mathrm{q}_{2}{ }^{2}\right) \Delta \mathrm{Q}^{2}+(1 / 2)\left(\mathrm{p}_{1} \mathrm{q}_{1}+\mathrm{p}_{2} \mathrm{q}_{2}\right) \Delta \mathrm{Q} \Delta \mathrm{P}-(1 / 4)\left(\mathrm{p}_{1}{ }^{2}+\right.$ $\left.\mathrm{p}_{2}{ }^{2}\right) \Delta \mathrm{P}^{2}$, so choose $\Delta \mathrm{P}^{\prime}$ to be the larger root of the quadratic.

Lemma 2: Too strong an incentive based on the alternative-use value makes relational outsourcing inferior to spot employment. That is, given $\mathrm{q}_{1}, \mathrm{q}_{2}, \mathrm{p}_{1}, \mathrm{p}_{2}$, and $\Delta \mathrm{Q}$ there exists $\Delta \beta^{\prime}$ such that, for any $\Delta b$, if $\Delta \beta>\Delta \beta^{\prime}$ then $S^{\mathrm{RO}}-\mathrm{S}^{\mathrm{SE}}<0$.

Proof: $\quad 2\left(\mathrm{~S}^{\mathrm{RO}}-\mathrm{S}^{\mathrm{SE}}\right)=\left(\mathrm{q}_{1}{ }^{2}+\mathrm{q}_{2}{ }^{2}\right) \Delta \mathrm{b}(2 \Delta \mathrm{Q}-\Delta \mathrm{b})+2\left(\mathrm{p}_{1} \mathrm{q}_{1}+\mathrm{p}_{2} \mathrm{q}_{2}\right)(\Delta \mathrm{Q}-\Delta \mathrm{b}) \Delta \beta-\left(\mathrm{p}_{1}{ }^{2}+\mathrm{p}_{2}{ }^{2}\right)$ $\Delta \beta^{2}$. Maximize the first term with respect to $\Delta \mathrm{b} \geq 0$ (at $\Delta \mathrm{b}=\Delta \mathrm{Q}$ ); maximize the second term with respect to $\Delta \mathrm{b} \geq 0$ (at $\Delta \mathrm{b}=0$ ). Now choose $\Delta \beta^{\prime}$ to be the larger root of the resulting quadratic, with the maximized versions of the first and second terms replacing the originals.

Lemma 3: Too large a variation in the alternative-use value makes relational outsourcing infeasible. That is, given $\mathrm{q}_{1}, \mathrm{q}_{2}, \mathrm{p}_{1}, \mathrm{p}_{2}, \Delta \mathrm{Q}$, and $\mathrm{r}$ there exists $\Delta \mathrm{P}^{\prime \prime}$ such that if $\Delta \mathrm{P}>$ $\Delta \mathrm{P}^{\prime \prime}$ then the reneging constraint (16') for relational outsourcing fails.

Proof: $\quad$ Choose $\Delta \mathrm{P}^{\prime \prime}$ such that $1 / 2 \Delta \mathrm{P}^{\prime \prime}>\Delta \beta^{\prime}+\left(\mathrm{S}^{*}-\mathrm{S}^{\mathrm{SE}}\right) / \mathrm{r}$, where $\mathrm{S}^{*}$ is the first-best surplus. If $\Delta \beta>\Delta \beta^{\prime}$ then Lemma 2 implies that $S^{R O}-S^{S E}<0$, so $S^{R O}-\max \left\{S^{S O}\right.$, $\left.\mathrm{S}^{\mathrm{SE}}\right\}<0$, so (16') fails. But $\Delta \beta^{\prime} \geq \Delta \beta$ implies $1 / 2 \Delta \mathrm{P}^{\prime \prime}>\Delta \beta$, so the second term on the lefthand side of $\left(16^{\prime}\right)$ is at least $1 / 2 \Delta \mathrm{P}^{\prime \prime}-\Delta \beta \geq 1 / 2 \Delta \mathrm{P}^{\prime \prime}-\Delta \beta^{\prime}>\left(\mathrm{S}^{*}-\mathrm{S}^{\mathrm{SE}}\right) / \mathrm{r} \geq\left(\mathrm{S}^{\mathrm{RO}}-\right.$ $\left.S^{S E}\right) / r \geq\left(S^{R O}-\max \left\{S^{S O}, S^{S E}\right\}\right) / r$, so (16') fails.

Result 2: High-powered incentives create bigger reneging temptations under integration than under non-integration, with the consequence that performance payments in relational incentive contracts will be smaller in firms than in (otherwise equivalent) markets. 
Formally, given $\mathrm{q}_{1}, \mathrm{q}_{2}, \mathrm{p}_{1}, \mathrm{p}_{2}, \Delta \mathrm{Q}, \Delta \mathrm{P}$, and $\mathrm{r}$, if the most efficient employment contract yields $a_{1}{ }^{\mathrm{RE}}<\mathrm{a}_{1}{ }^{\mathrm{FB}}$ and $\mathrm{a}_{2}{ }^{\mathrm{RE}}<\mathrm{a}_{2}{ }^{\mathrm{FB}}$ then either the most efficient outsourcing contract yields $a_{1}{ }^{R O}>a_{1}{ }^{R E}$ and $a_{2}{ }^{R O}>a_{2}{ }^{R E}$ or no relational-outsourcing contract exists.

Proof: Because relational employment yields actions below the first-best, the reneging constraint (10') must bind. Consider implementing the same incentives, $\Delta \mathrm{b}$ and $\Delta \beta$, through relational outsourcing instead of employment. Given the same incentives, the same actions would result, but the reneging constraint (16') would differ. If $\Delta b$ $\geq 1 / 2 \Delta \mathrm{Q}$ and $\Delta \beta \geq 1 / 2 \Delta \mathrm{P}$ then the lefthand side of (16') is smaller than the lefthand side of (10'), but the righthand sides are identical, so (16') is slack, so the actions in the efficient relational-outsourcing contract can be increased from those in the efficient relational-employment contract. Alternatively, if $\Delta \mathrm{b}<1 / 2 \Delta \mathrm{Q}$ and/or $\Delta \beta<$ $1 / 2 \Delta \mathrm{P}$ then it may be that no relational-outsourcing contract is feasible. But if relational outsourcing is feasible then a small increase in $\Delta \mathrm{b}$ (if $\Delta \mathrm{b}<1 / 2 \Delta \mathrm{Q}$ ) and/or $\Delta \beta$ (if $\Delta \beta<1 / 2 \Delta \mathrm{P}$ ) increases the actions while reducing the lefthand side of (16'). Hence, it will not be efficient for the incentives in the relational-outsourcing contract to be as weak as those under relational employment.

Result 3: The optimal integration decision can depend on the discount rate. Formally, there exist parameters $\mathrm{q}_{1}, \mathrm{q}_{2}, \mathrm{p}_{1}, \mathrm{p}_{2}, \Delta \mathrm{Q}, \Delta \mathrm{P}$ such that at intermediate discount rates the first-best can be achieved by relational employment but not by relational outsourcing, but at high discount rates no relational contract is feasible and spot outsourcing yields higher total surplus than does spot employment.

Proof: The elements of the proof have already been given in various places in the text. As noted just after (19) and (20), if $\Delta \mathrm{P}>\Delta \mathrm{Q}$ then there exist discount rates at which the first-best is feasible under relational employment but not under relational outsourcing. But as noted in the second paragraph of subsection IV.B, in our unproductive-multitasking example, spot outsourcing dominates spot employment if $\mathrm{p} \Delta \mathrm{P}>\sqrt{3} \mathrm{q} \Delta \mathrm{Q}$. Thus, for $\Delta \mathrm{Q}<\Delta \mathrm{P}<\sqrt{3}(\mathrm{q} / \mathrm{p}) \Delta \mathrm{Q}$, an increase in $\mathrm{r}$ can move the efficient organizational form from first-best relational employment to spot outsourcing, as shown by the arrow labeled R3 in Figure II.

Result 4: Holding all marginal incentives constant, the optimal integration decision can depend on the payoff levels. Formally, holding $\mathrm{q}_{\mathrm{i}} \Delta \mathrm{Q}+\mathrm{p}_{\mathrm{i}} \Delta \mathrm{P}$ constant for $\mathrm{i}=1,2$ fixes 
the choice between spot employment or spot outsourcing, but changing $\Delta \mathrm{P}$ or $\Delta \mathrm{Q}$ (with corresponding changes in $\mathrm{p}_{\mathrm{i}}$ or $\mathrm{q}_{\mathrm{i}}$ to keep $\mathrm{q}_{\mathrm{i}} \Delta \mathrm{Q}+\mathrm{p}_{\mathrm{i}} \Delta \mathrm{P}$ constant) affects the reneging temptations and hence the choice between relational employment and relational outsourcing.

Proof: Given $\mathrm{q}_{1}, \mathrm{q}_{2}, \mathrm{p}_{1}, \mathrm{p}_{2}, \Delta \mathrm{Q}$, and $\Delta \mathrm{P}$, define $\mathrm{r}^{*}$ such that (19) holds with equality. For $\mathrm{r}=$ $\mathrm{r}^{*}$, if $\Delta \mathrm{P}>\Delta \mathrm{Q}$ then (16) fails, but if $\Delta \mathrm{P}<\Delta \mathrm{Q}$ then (20) holds strictly. Suppose $\Delta \mathrm{P}>$ $\Delta \mathrm{Q}$. (The proof for $\Delta \mathrm{P}<\Delta \mathrm{Q}$ is analogous.) Choose some $\Delta \mathrm{P}^{\prime}<\Delta \mathrm{Q}$ and define $\mathrm{p}_{\mathrm{I}}^{\prime}=$ $\mathrm{p}_{\mathrm{i}} \Delta \mathrm{P} / \Delta \mathrm{P}^{\prime}$ for $\mathrm{i}=1,2$, so that $\mathrm{q}_{\mathrm{i}} \Delta \mathrm{Q}+\mathrm{p}_{\mathrm{i}} \Delta \mathrm{P}=\mathrm{q}_{\mathrm{i}} \Delta \mathrm{Q}+\mathrm{p}_{\mathrm{i}}{ }^{\prime} \Delta \mathrm{P}^{\prime}$ for $\mathrm{i}=1,2$. Then (20) fails for $\left(\mathrm{q}_{1}, \mathrm{q}_{2}, \mathrm{p}_{1}, \mathrm{p}_{2}, \Delta \mathrm{Q}, \Delta \mathrm{P}, \mathrm{r}^{*}\right)$ but holds strictly for $\left(\mathrm{q}_{1}, \mathrm{q}_{2}, \mathrm{p}_{1}{ }^{\prime}, \mathrm{p}_{2}{ }^{\prime}, \Delta \mathrm{Q}, \Delta \mathrm{P}^{\prime}, \mathrm{r}^{*}\right)$. Now consider $\mathrm{r}^{* *}$ just above $\mathrm{r}^{*}$, so that (19) just fails at $\left(\mathrm{q}_{1}, \mathrm{q}_{2}, \mathrm{p}_{1}, \mathrm{p}_{2}, \Delta \mathrm{Q}, \Delta \mathrm{P}, \mathrm{r}^{* *}\right)$ but the second-best relational employment contract at $\left(\mathrm{q}_{1}, \mathrm{q}_{2}, \mathrm{p}_{1}, \mathrm{p}_{2}, \Delta \mathrm{Q}, \Delta \mathrm{P}, \mathrm{r}^{* *}\right)$ is only slightly worse than first-best. In particular, for $\mathrm{r}^{* *}$ sufficiently close to $\mathrm{r}^{*}$, the second-best relational employment contract at $\left(\mathrm{q}_{1}, \mathrm{q}_{2}, \mathrm{p}_{1}, \mathrm{p}_{2}, \Delta \mathrm{Q}, \Delta \mathrm{P}, \mathrm{r}^{* *}\right)$ will generate higher surplus than the second-best relational outsourcing contract at $\left(\mathrm{q}_{1}\right.$, $\left.\mathrm{q}_{2}, \mathrm{p}_{1}, \mathrm{p}_{2}, \Delta \mathrm{Q}, \Delta \mathrm{P}, \mathrm{r}^{* *}\right)$ because $\Delta \mathrm{P}>\Delta \mathrm{Q}$. Thus, at $\left(\mathrm{q}_{1}, \mathrm{q}_{2}, \mathrm{p}_{1}{ }^{\prime}, \mathrm{p}_{2}{ }^{\prime}, \Delta \mathrm{Q}, \Delta \mathrm{P}^{\prime}, \mathrm{r}^{* *}\right)$ the first-best can be achieved under relational outsourcing but not under relational employment, but at $\left(\mathrm{q}_{1}, \mathrm{q}_{2}, \mathrm{p}_{1}, \mathrm{p}_{2}, \Delta \mathrm{Q}, \Delta \mathrm{P}, \mathrm{r}^{* *}\right)$ relational outsourcing is strictly worse than first-best while relational employment is arbitrarily close to first-best.

Result 5: A mediocre spot market may prevent the existence of any firm, including a firm that would be more efficient than the spot market. Formally, suppose that $\mathrm{q}_{1}, \mathrm{q}_{2}, \mathrm{p}_{1}, \mathrm{p}_{2}$, $\Delta \mathrm{Q}$, and $\Delta \mathrm{P}$ imply that spot outsourcing dominates spot employment $\left(\mathrm{S}^{\mathrm{SO}}>\mathrm{S}^{\mathrm{SE}}\right)$. Then there exists $r^{*}$ such that if $r>r^{*}$ then no values of $\Delta b$ and $\Delta \beta$ satisfy the reneging constraint $\left(10^{\prime}\right)$.

Proof: $\quad$ Given Lemma 4 below, Result 5 follows because $\mathrm{S}^{\mathrm{SO}}>\mathrm{S}^{\mathrm{SE}}$.

Lemma 4: For sufficiently high $\mathrm{r}$, the only possible relational-employment contract is the trivial case of $\Delta b=\Delta \beta=0$ (i.e., replication of spot employment). That is, given $\mathrm{q}_{1}, \mathrm{q}_{2}, \mathrm{p}_{1}$, $\mathrm{p}_{2}, \Delta \mathrm{Q}$ and $\Delta \mathrm{P}$ there exists $\mathrm{r}_{\mathrm{D}} *$ such that if $\mathrm{r}>\mathrm{r}_{\mathrm{D}} *$ then no values of $\Delta \mathrm{b}$ and $\Delta \beta$ satisfy the reneging constraint (10') except perhaps $\Delta b=\Delta \beta=0$.

Proof: $\quad$ The reneging constraint (10') holds only if $|\Delta \mathrm{b}|+|\Delta \beta| \leq\left(\mathrm{S}^{\mathrm{RE}}-\mathrm{S}^{\mathrm{SE}}\right) / \mathrm{r}$. But this inequality can be written as

$$
2 \mathrm{r}(\Delta \mathrm{b}+\Delta \beta)+\left(\mathrm{a}_{1}{ }^{\mathrm{RE}}-\mathrm{q}_{1} \Delta \mathrm{Q}\right)^{2}+\left(\mathrm{a}_{2}{ }^{\mathrm{RE}}-\mathrm{q}_{2} \Delta \mathrm{Q}\right)^{2} \leq\left(\mathrm{q}_{1}{ }^{2}+\mathrm{q}_{2}{ }^{2}\right) \Delta \mathrm{Q}^{2},
$$


where $\mathrm{a}_{\mathrm{i}}{ }^{\mathrm{RE}}=\mathrm{q}_{\mathrm{i}} \Delta \mathrm{b}+\mathrm{p}_{\mathrm{i}} \Delta \beta$. Note that at $\Delta \mathrm{b}=\Delta \beta=0$ we have $\mathrm{a}_{1}{ }^{\mathrm{RE}}=\mathrm{a}_{2}{ }^{\mathrm{RE}}=0$, so (A2.1) holds with equality. We will show that for sufficiently high values of $r$, values of $\Delta b$ and/or $\Delta \beta$ other than zero increase the lefthand side of (A2.1), but the righthand side is constant, so the reneging constraint (10') fails unless $\Delta b=\Delta \beta=0$.

Let $\mathrm{L}_{\mathrm{D}}(\Delta \mathrm{b}, \Delta \beta)$ denoted the lefthand side of $(\mathrm{A} 2.1)$. Then $\partial \mathrm{L}_{\mathrm{D}} / \partial \Delta \mathrm{b}=2 \mathrm{r}+2\left(\mathrm{a}_{1}{ }^{\mathrm{RE}}-\right.$ $\left.\mathrm{q}_{1} \Delta \mathrm{Q}\right) \mathrm{q}_{1}+2\left(\mathrm{a}_{2}{ }^{\mathrm{RE}}-\mathrm{q}_{2} \Delta \mathrm{Q}\right) \mathrm{q}_{2}$. Because $\mathrm{a}_{1}{ }^{\mathrm{RE}}$ and $\mathrm{a}_{2}{ }^{\mathrm{RE}} \geq 0$, we have that if $\mathrm{r}>\left(\mathrm{q}_{1}{ }^{2}+\right.$ $\left.\mathrm{q}_{2}{ }^{2}\right) \Delta \mathrm{Q}$ then $\partial \mathrm{L}_{\mathrm{D}} / \partial \Delta \mathrm{b}>0$. Similarly, $\partial \mathrm{L}_{\mathrm{D}} / \partial \Delta \beta=2 \mathrm{r}+2\left(\mathrm{a}_{1}{ }^{\mathrm{RE}}-\mathrm{q}_{1} \Delta \mathrm{Q}\right) \mathrm{p}_{1}+2\left(\mathrm{a}_{2}{ }^{\mathrm{RE}}-\right.$ $\left.\mathrm{q}_{2} \Delta \mathrm{Q}\right) \mathrm{p}_{2}$, so if $\mathrm{r}>\left(\mathrm{p}_{1} \mathrm{q}_{1}+\mathrm{p}_{2} \mathrm{q}_{2}\right) \Delta \mathrm{Q}$ then $\partial \mathrm{L}_{\mathrm{D}} / \partial \Delta \beta>0$. Let $\mathrm{r}_{\mathrm{D}}{ }^{*}=\max \left\{\left(\mathrm{q}_{1}{ }^{2}+\mathrm{q}_{2}{ }^{2}\right) \Delta \mathrm{Q}\right.$, $\left.\left(\mathrm{p}_{1} \mathrm{q}_{1}+\mathrm{p}_{2} \mathrm{q}_{2}\right) \Delta \mathrm{Q}\right\}$. Then for $\mathrm{r}>\mathrm{r}_{\mathrm{D}}{ }^{*}$ we have that (A2.1) fails and hence that $\left(10^{\prime}\right)$ fails, except perhaps at $\Delta \mathrm{b}=\Delta \beta=0$.

Result 5: Mediocre spot employment may prevent the existence of any outsourcing. Formally, suppose that $\mathrm{q}_{1}, \mathrm{q}_{2}, \mathrm{p}_{1}, \mathrm{p}_{2}, \Delta \mathrm{Q}$, and $\Delta \mathrm{P}$ imply that spot employment dominates spot outsourcing $\left(S^{S E}>S^{S O}\right)$. Then there exists $r^{*}$ such that if $r>r^{*}$ then no values of $\Delta b$ and $\Delta \beta$ satisfy the reneging constraint (16').

Proof: $\quad$ Given Lemma 4 below, Result 5 follows because $\mathrm{S}^{\mathrm{SE}}>\mathrm{S}^{\mathrm{SO}}$.

Lemma 5: For sufficiently high $\mathrm{r}$, the only possible relational-outsourcing contract is the trivial case of $\Delta \mathrm{b}=1 / 2 \Delta \mathrm{Q}$ and $\Delta \beta=1 / 2 \Delta \mathrm{P}$ (i.e., replication of spot outsourcing). That is, given $\mathrm{q}_{1}, \mathrm{q}_{\mathrm{2}}, \mathrm{p}_{1}, \mathrm{p}_{2}, \Delta \mathrm{Q}$ and $\Delta \mathrm{P}$ there exists $\mathrm{r}_{\mathrm{U}}{ }^{*}$ such that if $\mathrm{r}>\mathrm{r}_{\mathrm{U}}{ }^{*}$ then no values of $\Delta \mathrm{b}$ and $\Delta \beta$ satisfy the reneging constraint (16') except perhaps $\Delta \mathrm{b}=1 / 2 \Delta \mathrm{Q}$ and $\Delta \beta=$ $1 / 2 \Delta \mathrm{P}$.

Proof: $\quad$ The reneging constraint (16') holds only if $|\Delta \mathrm{b}-1 / 2 \Delta \mathrm{Q}|+|\Delta \beta-1 / 2 \Delta \mathrm{P}| \leq\left(\mathrm{S}^{\mathrm{RO}}-\right.$ $\left.\mathrm{S}^{\mathrm{SO}}\right) / \mathrm{r}$. But this inequality can be written as

$$
\begin{gathered}
2 \mathrm{r}|\Delta \mathrm{b}-1 / 2 \Delta \mathrm{Q}|+2 \mathrm{r}|\Delta \beta-1 / 2 \Delta \mathrm{P}|+\left(\mathrm{a}_{1}{ }^{\mathrm{RO}}-\mathrm{q}_{1} \Delta \mathrm{Q}\right)^{2}+\left(\mathrm{a}_{2}{ }^{\mathrm{RO}}-\mathrm{q}_{2} \Delta \mathrm{Q}\right)^{2} \\
\leq\left(\mathrm{a}_{1}{ }^{\text {SO }}-\mathrm{q}_{1} \Delta \mathrm{Q}\right)^{2}+\left(\mathrm{a}_{2}{ }^{\text {so }}-\mathrm{q}_{2} \Delta \mathrm{Q}\right)^{2}
\end{gathered}
$$

where $\mathrm{a}_{\mathrm{i}}^{\mathrm{RO}}=\mathrm{q}_{\mathrm{i}} \Delta \mathrm{b}+\mathrm{p}_{\mathrm{i}} \Delta \beta$ and $\mathrm{a}_{\mathrm{i}}^{\mathrm{SO}}==1 / 2 \mathrm{q}_{\mathrm{i}} \Delta \mathrm{Q}+1 / 2 \mathrm{p}_{\mathrm{i}} \Delta \mathrm{P}$. Note that at $\Delta \mathrm{b}=1 / 2 \Delta \mathrm{Q}$ and $\Delta \beta=1 / 2 \Delta \mathrm{P}$ we have $\mathrm{a}_{\mathrm{i}}^{\mathrm{RO}}=\mathrm{a}_{\mathrm{i}}^{\text {SO }}$, so (A2.2) holds with equality. We will show that for sufficiently high values of $\mathrm{r}$, values of $\Delta \mathrm{b}$ and/or $\Delta \beta$ other than $1 / 2 \Delta \mathrm{Q}$ and $1 / 2 \Delta \mathrm{P}$ increase the lefthand side of (A2.2), but the righthand side is constant, so the reneging constraint (16') fails except perhaps at $\Delta \mathrm{b}=1 / 2 \Delta \mathrm{Q}$ and $\Delta \beta=1 / 2 \Delta \mathrm{P}$.

Let $\mathrm{L}_{\mathrm{U}}(\Delta \mathrm{b}, \Delta \beta)$ denoted the lefthand side of (A2.2). For $\Delta \mathrm{b}>1 / 2 \Delta \mathrm{Q}$ we have $\partial \mathrm{L}_{\mathrm{U}} / \partial \Delta \mathrm{b}$ $=2 \mathrm{r}+2\left(\mathrm{a}_{1}{ }^{\mathrm{RO}}-\mathrm{q}_{1} \Delta \mathrm{Q}\right) \mathrm{q}_{1}+2\left(\mathrm{a}_{2}{ }^{\mathrm{RO}}-\mathrm{q}_{2} \Delta \mathrm{Q}\right) \mathrm{q}_{2}$. Because $\mathrm{a}_{1}{ }^{\mathrm{RO}}$ and $\mathrm{a}_{2}{ }^{\mathrm{RO}} \geq 0$, we have 
that if $\mathrm{r}>\left(\mathrm{q}_{1}{ }^{2}+\mathrm{q}_{2}{ }^{2}\right) \Delta \mathrm{Q}$ then $\partial \mathrm{L}_{\mathrm{U}} / \partial \Delta \mathrm{b}>0$ for $\Delta \mathrm{b}>1 / 2 \Delta \mathrm{Q}$. For $\Delta \mathrm{b}<1 / 2 \Delta \mathrm{Q}$ we have $\partial \mathrm{L}_{\mathrm{U}} / \partial \Delta \mathrm{b}=-2 \mathrm{r}+2\left(\mathrm{a}_{1}{ }^{\mathrm{RO}}-\mathrm{q}_{1} \Delta \mathrm{Q}\right) \mathrm{q}_{1}+2\left(\mathrm{a}_{2}^{\mathrm{RO}}-\mathrm{q}_{2} \Delta \mathrm{Q}\right) \mathrm{q}_{2}$. We wish to show that if $\mathrm{r}$ is sufficiently high then $\partial \mathrm{L}_{\mathrm{U}} / \partial \Delta \mathrm{b}<0$ for $\Delta \mathrm{b}<1 / 2 \Delta \mathrm{Q}$. It therefore suffices to establish an upper bound on $\mathrm{q}_{1} \mathrm{a}_{1}{ }^{\mathrm{RO}}+\mathrm{q}_{2} \mathrm{a}_{2}{ }^{\mathrm{RO}}$. Because $\mathrm{a}_{\mathrm{i}}{ }^{\mathrm{RO}}=\mathrm{q}_{\mathrm{i}} \Delta \mathrm{b}+\mathrm{p}_{\mathrm{i}} \Delta \beta$ and $\Delta \mathrm{b}<1 / 2 \Delta \mathrm{Q}$, it suffices to establish an upper bound on $\Delta \beta$. This is done in Lemma 6 .

Similarly, for $\Delta \beta>1 / 2 \Delta \mathrm{P}$ we have $\partial \mathrm{L}_{\mathrm{U}} / \partial \Delta \beta=2 \mathrm{r}+2\left(\mathrm{a}_{1}{ }^{\mathrm{RO}}-\mathrm{q}_{1} \Delta \mathrm{Q}\right) \mathrm{p}_{1}+2\left(\mathrm{a}_{2}{ }^{\mathrm{RO}}-\right.$ $\left.\mathrm{q}_{2} \Delta \mathrm{Q}\right) \mathrm{p}_{2}$. Because $\mathrm{a}_{1}{ }^{\mathrm{RO}}$ and $\mathrm{a}_{2}{ }^{\mathrm{RO}} \geq 0$, we have that if $\mathrm{r}>\left(\mathrm{p}_{1} \mathrm{q}_{1}+\mathrm{p}_{2} \mathrm{q}_{2}\right) \Delta \mathrm{Q}$ then $\partial \mathrm{L}_{\mathrm{U}} / \partial \Delta \beta>0$ for $\Delta \beta>1 / 2 \Delta \mathrm{P}$. For $\Delta \beta<1 / 2 \Delta \mathrm{P}$ we have $\partial \mathrm{L}_{\mathrm{U}} / \partial \Delta \beta=-2 \mathrm{r}+2\left(\mathrm{a}_{1}{ }^{\mathrm{RO}}-\right.$ $\left.\mathrm{q}_{1} \Delta \mathrm{Q}\right) \mathrm{p}_{1}+2\left(\mathrm{a}_{2}{ }^{\mathrm{RO}}-\mathrm{q}_{2} \Delta \mathrm{Q}\right) \mathrm{p}_{2}$. We wish to show that if $\mathrm{r}$ is sufficiently high then $\partial \mathrm{L}_{\mathrm{U}} / \partial \Delta \beta<0$ for $\Delta \beta<1 / 2 \Delta \mathrm{Q}$. It therefore suffices to establish an upper bound on $\mathrm{p}_{1} \mathrm{a}_{1}{ }^{R O}+\mathrm{p}_{2} \mathrm{a}_{2}{ }^{\mathrm{RO}}$. Because $\mathrm{a}_{\mathrm{i}}{ }^{\mathrm{RO}}=\mathrm{q}_{\mathrm{i}} \Delta \mathrm{b}+\mathrm{p}_{\mathrm{i}} \Delta \beta$ and $\Delta \beta<1 / 2 \Delta \mathrm{P}$, it suffices to establish an upper bound on $\Delta b$. This is done in Lemma 7 .

Let $\mathrm{r}_{\mathrm{U}} *$ be the maximum of $\left(\mathrm{q}_{1}{ }^{2}+\mathrm{q}_{2}{ }^{2}\right) \Delta \mathrm{Q},\left(\mathrm{p}_{1} \mathrm{q}_{1}+\mathrm{p}_{2} \mathrm{q}_{2}\right) \Delta \mathrm{Q}$, and the two other values of $r$ determined above. Then for $r>r_{U}{ }^{*}$ we have that (A2.2) fails and hence that (16') fails, except perhaps at $\Delta \mathrm{b}=1 / 2 \Delta \mathrm{Q}$ and $\Delta \beta=1 / 2 \Delta \mathrm{P}$.

Lemma 6: Too strong an incentive based on the alternative-use value makes relational outsourcing inferior to spot outsourcing. That is, given $\mathrm{q}_{1}, \mathrm{q}_{2}, \mathrm{p}_{1}, \mathrm{p}_{2}$, and $\Delta \mathrm{Q}$ there exists $\Delta \beta^{\prime \prime}$ such that, for any $\Delta b$, if $\Delta \beta>\Delta \beta^{\prime \prime}$ then $S^{R O}-S^{S O}<0$.

Proof: $\quad 2\left(\mathrm{~S}^{\mathrm{RO}}-\mathrm{S}^{\mathrm{SO}}\right)=\mathrm{K}(\Delta \mathrm{b})+2\left(\mathrm{p}_{1} \mathrm{q}_{1}+\mathrm{p}_{2} \mathrm{q}_{2}\right)(\Delta \mathrm{Q}-\Delta \mathrm{b}) \Delta \beta-\left(\mathrm{p}_{1}{ }^{2}+\mathrm{p}_{2}{ }^{2}\right) \Delta \beta^{2}$. As in the proof of Lemma 2, maximize $\mathrm{K}(\Delta \mathrm{b})$ with respect to $\Delta \mathrm{b} \geq 0$, and maximize the second term with respect to $\Delta \mathrm{b} \geq 0$ (at $\Delta \mathrm{b}=0$ ). Now choose $\Delta \beta "$ to be the larger root of the resulting quadratic, with the maximized versions of the first and second terms replacing the originals.

Lemma 7: Too strong an incentive based on the downstream value makes relational outsourcing inferior to spot outsourcing. That is, given $\mathrm{q}_{1}, \mathrm{q}_{2}, \mathrm{p}_{1}, \mathrm{p}_{2}$, and $\Delta \mathrm{Q}$ there exists $\Delta \mathrm{b}^{\prime \prime}$ such that, for any $\Delta \beta$, if $\Delta b>\Delta b^{\prime \prime}$ then $S^{R O}-S^{S O}<0$.

Proof: $\quad 2\left(\mathrm{~S}^{\mathrm{RO}}-\mathrm{S}^{\mathrm{SO}}\right)=\mathrm{M}(\Delta \beta)+2\left\{\left(\mathrm{q}_{1}{ }^{2}+\mathrm{q}_{2}{ }^{2}\right) \Delta \mathrm{Q}-\left(\mathrm{p}_{1} \mathrm{q}_{1}+\mathrm{p}_{2} \mathrm{q}_{2}\right) \Delta \beta\right\} \Delta \mathrm{b}-\left(\mathrm{q}_{1}{ }^{2}+\mathrm{q}_{2}{ }^{2}\right) \Delta \mathrm{b}^{2}$. As in the proof of Lemma 2, maximize $\mathrm{M}(\Delta \beta)$ with respect to $\Delta \beta \geq 0$, and maximize the second term with respect to $\Delta \beta \geq 0$ (at $\Delta \beta=0$ ). Now choose $\Delta \mathrm{b}^{\prime \prime}$ to be the larger root of the resulting quadratic, with the maximized versions of the first and second terms replacing the originals. 


\section{REFERENCES}

Arrow, Kenneth, "Vertical Integration and communication," Bell Journal of Economics, VI (1975), 173-83.

Baker, George, Robert Gibbons and Kevin J. Murphy, "Subjective Performance Measures in Optimal Incentive Contracts," Quarterly Journal of Economics, CIX (1994), 1125-56.

and , "Bringing the Market Inside the Firm?," forthcoming in American Economic Review (2001).

Barnard, Chester, The Functions of the Executive, Cambridge, MA: Harvard University Press (1938).

Bernheim, Douglas and Michael Whinston, "Incomplete Contracts and Strategic Ambiguity," American Economic Review, LXXXVIII (1998), 902-32.

Blau, Peter, The Dynamics of Bureaucracy, Chicago, IL: University of Chicago Press (1955).

and Richard Scott, Formal Organizations: A Comparative Approach, San Francisco, CA: Chandler Publishing (1962).

Blumenstein, Rebecca and Gabriella Stern, "UAW, Auto Makers Find Some Things Better Left Unsaid,” Wall Street Journal, November 25, 1996.

Bower, Joseph, Managing the Resource Allocation Process, Boston, MA: Harvard Business School Press (1970).

Bragelien, Iver, "Asset Ownership and Implicit Contracts." Unpublished manuscript, Norwegian School of Business (2000).

Bull, Clive, "The Existence of Self-Enforcing Implicit Contracts," Quarterly Journal of Economics, CII (1987) 147-59.

Carlton, Dennis, "Vertical Integration in Competitive Markets Under Uncertainty," Journal of Industrial Economics, XXXVII (1979), 189-209.

Che, Yeon-Koo, and Seung-Weon Yoo, "Optimal Incentives for Teams," Forthcoming in American Economic Review.

Chesbrough, Henry and David Teece, "When is Virtual Virtuous? Organizing for Innovation," Harvard Business Review, January-February (1996), 65-73.

Coase, Ronald, “The Nature of the Firm,” Economica, IV (1937), 386-405.

Cusumano, Michael and Akira Takeishi, "Supplier Relations and Management: A Survey of Japanese, Japanese-Transplant, and U.S. Auto Plants,” Strategic Management Journal, XII (1991), 563-88.

Dalton, Melville, Men Who Manage, New York: Wiley (1959). 
Dechow, Patricia, Mark Huson and Richard Sloan, "The Effect of Restructuring Charges on Executives' Cash Compensation,” Accounting Review, LXIX (1994), 138-56.

DeMeza, David and Ben Lockwood, "Does Asset Ownership Always Motivate Managers? Outside Options and the Property Rights Theory of the Firm," Quarterly Journal of Economics, CXIII (1999), 361-386.

Dore, Ronald, "Goodwill and the Spirit of Market Capitalism," British Journal of Sociology, XXXIV (1983), 459-82.

Dyer, Jeffrey, "How Chrysler Created an American Keiretsu," Harvard Business Review (1996), July-August, 32-46.

Eccles, Robert, The Transfer Pricing Problem, Lexington, MA:D. C. Heath (1985).

Garvey, Gerald, "Why Reputation Favors Joint Ventures over Vertical and Horizontal Integration: A Simple Model," Journal of Economic Behavior and Organization XXVIII (1995), 387-97.

Gerlach, Michael, Alliance Capitalism: The Social Organization of Japanese Businesses, Berkeley, CA: University of California Press (1991).

Goldberg, Victor P. and John R. Erickson, "Quantity and Price Adjustment in Long-Term Contracts: A Case Study of Petroleum Coke," Journal of Law and Economics, XXX (1987), 369-398.

Gould, J.R., "Transfer Pricing in Firms When There Are Costs of Using an Outside Market," Journal of Business, XXXVII (1964), 61-67.

Gouldner, Alvin, Patterns of Industrial Bureaucracy, New York, NY: The Free Press (1954).

Granovetter, Mark, "Economic Action and Social Structure: The Problem of Embeddedness," American Journal of Sociology, XCI (1985), 481-510.

, "Coase Revisited: Business Groups in the Modern Economy," Industrial and Corporate Change, IV (1995), 93-130.

Grossman, Sanford and Oliver Hart, "The Costs and Benefits of Ownership: A Theory of Vertical and Lateral Ownership," Journal of Political Economy, XCIV (1986), 691-719.

Gulati, Ranjay and Harbir Singh, "The Architecture of Cooperation: Managing Coordination Costs and Appropriation Concerns in Strategic Alliances," Administrative Science Quarterly, XLIII (1998), 781-814.

Hart, Oliver, Firms, Contracts, and Financial Structure, Oxford: Clarendon Press (1995).

and John Moore, "Property Rights and the Nature of the Firm," Journal of Political Economy XCVIII (1990), 1119-58.

Halonen, Maija, "Reputation and Allocation of Ownership," Working Paper, Helsinki School of Economics (1994).

Hirshleifer, Jack, “On the Economics of Effective Intracompany Pricing," Journal of Business, XXIX (1956), 172-84. 
Holmstrom, Bengt, "The Firm as a Subeconomy," Journal of Law, Economics, and Organization XV (1999), 74-102.

and Paul Milgrom, "Multitask Principal-Agent Analyses: Incentive Contracts, Asset Ownership, and Job Design," Journal of Law, Economics, and Organization, VII (1991), 24-52.

and Jean Tirole, "Transfer Pricing and Organizational Form," Journal of Law, Economics, and Organization, VII (1991), 201-28.

Kahn, Charles and Gur Huberman, "Two-sided Uncertainty and 'Up-or-Out' Contract," Journal of Labor Economics, VI (1988), 423-44.

Klein, Benjamin, "Why Hold-ups Occur: The Self-Enforcing Range of Contractual Relationships," Economic Inquiry, XXXIV (1996), 444-63.

, "Fisher-General Motors and the Nature of the Firm," Journal of Law and Economics, XLIII (2000), 105-41.

, Robert Crawford, and Armen Alchian, "Vertical Integration, Appropriable Rents and the Competitive Contracting Process," Journal of Law and Economics XXI (1978), 297-326.

and Keith Leffler, "The Role of Market Forces in Assuring Contractual Performance," Journal of Political Economy, LXXXIX (1981), 615-641.

and Kevin M. Murphy, "Vertical Restraints as Contract Enforcement Mechanisms," Journal of Law and Economics, XXXI (1988): 265-97.

and "Vertical Integration as a Self-Enforcing Contractual Arrangement," American Economic Review, LXXXVII (1997), 415-20.

Kogut, Bruce, “The Stability of Joint Ventures: Reciprocity and Competitive Rivalry,” Journal of Industrial Economics, XXXVIII (1989), 183-98.

Kole, Stacey, "The Complexity of Compensation Contracts," Journal of Financial Economics, XLIII (1997), 79-104.

Kreps, David, "Corporate Culture and Economic Theory," in J. Alt and K. Shepsle, eds. Perspectives on Positive Political Economy, Cambridge University Press (1990).

Lawler, Edward, Pay and Organizational Effectiveness: A Psychological View, New York, NY: McGraw-Hill (1971).

Levin, Jonathan, "Relational Incentive Contracts," Working Paper, Stanford University (2000).

Lorsch, Jay and Elizabeth McIver, Pawn and Potentates: The Reality of America's Corporate Boards, Boston, MA: Harvard Business School Press (1994).

Macaulay, Stewart, "Non Contractual Relations in Business: A Preliminary Study," American Sociological Review, XXVIII (1963), 55-67.

MacLeod, Bentley and James Malcolmson, "Implicit contracts, Incentive Compatibility, and Involuntary Unemployment,” Econometrica, LVII (1989) 447-80. 

411 , "Motivation and Markets,” American Economic Review, LXXXVIII (1998), 388-

Macneil, Ian, "Contracts: Adjustments of long-term economic relations under classical, neoclassical, and relational contract law," Northwestern University Law Review, LCCII (1978), 854-906.

Maskin, Eric and Jean Tirole, "Two Remarks on Property Rights," Review of Economic Studies LXVI (1999), 139-49.

Miles, Raymond and Charles Snow, "Causes of Failure in Network Organizations," California Management Review, XXXIV (1992), 53-72.

Nishiguchi, Toshihiro, Strategic Industrial Sourcing: The Japanese Advantage, New York, NY: Oxford University Press (1994).

Pisano, Gary, "Using Equity Participation to Support Exchange: Evidence from the Biotechnology Industry," Journal of Law, Economics, and Organization , V (1989), 109-26.

Podolny, Joel, and Karen Page, "Network Forms of Organization," Annual Review of Sociology, XXIV (1998), 57-76.

Powell, Walter, "Neither Market nor Hierarchy: Network Forms of Organization," Research in Organizational Behavior, XII (1990), 295-336.

Rey, Patrick and Jean Tirole, "Divergence of Objectives and the Governance of Joint Ventures," Working Paper, IDEI (1999).

Sako, Mari and Susan Helper, "Determinants of trust in supplier relations: Evidence from the automotive industry in Japan and the United States," Journal of Economic Behavior and Organization, XXXIV (1998), 387-417.

Selznick, Philip, TVA and the Grass Roots, Berkeley, CA: University of California Press (1949).

Simon, Herbert, “A Formal Theory Model of the Employment Relationship," Econometrica, XIX (1951), 293-305. Administrative Behavior, New York, NY: The Free Press $(1947,1976)$.

Telser, Lester, “A Theory of Self-Enforcing Agreements,” Journal of Business, LIII (1981), 27-44.

Whinston, Michael, "On the Transaction Cost Determinants of Vertical Integration," Unpublished manuscript, Northwestern Universtiy (2000).

Williamson, Oliver, Markets and Hierarchies: Analysis and Antitrust Implications, New York, NY: Free Press (1975).

, The Economic Institutions of Capitalism, New York, NY: Free Press (1985). (1996)

The Mechanisms of Governance, New York, NY: Oxford University Press 


\section{Figure I}

Combinations of ownership and governance regimes that define four organizational forms: Spot Outsourcing, Spot Employment, Relational Outsourcing, and Relational Employment

\begin{tabular}{|c|c|c|}
\hline \multirow[b]{2}{*}{ Governance Environment } & \multicolumn{2}{|c|}{ Ownership Environment } \\
\hline & $\begin{array}{l}\text { Non-Integrated } \\
\text { Asset Ownership }\end{array}$ & $\begin{array}{c}\text { Integrated } \\
\text { Asset Ownership }\end{array}$ \\
\hline Spot & Spot Outsourcing & Spot Employment \\
\hline Relational & Relational Outsourcing & Relational Employment \\
\hline
\end{tabular}




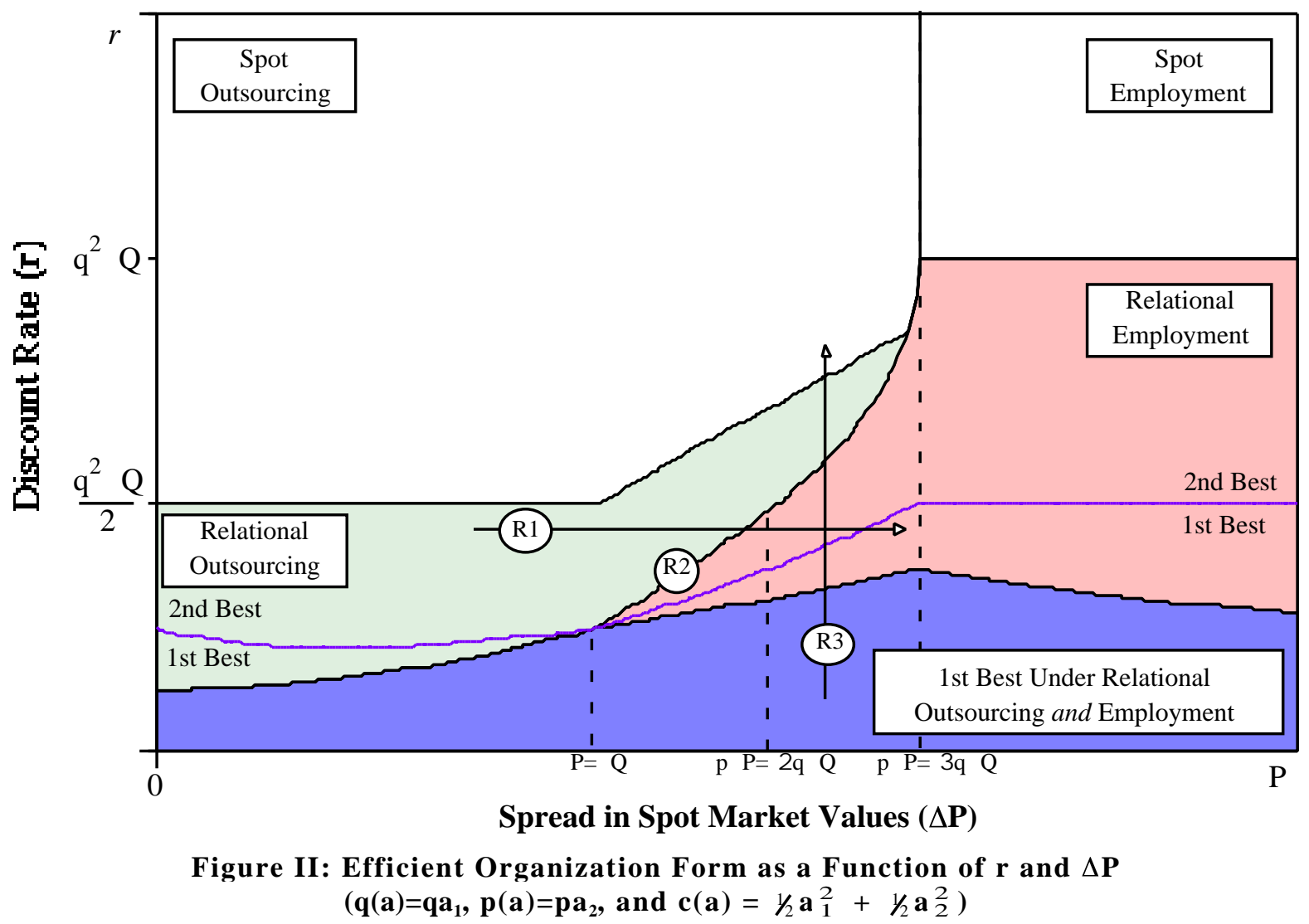

The figure shows how the efficient organizational form varies with the discount rate (r) and the difference between the high and low market valuations $(\Delta \mathrm{P})$, assuming that $\mathrm{p}=\mathrm{q}=1$. Our first three results are illustrated in (R1) through (R3) (see the text for a complete discussion). 